\title{
"Things change you know": Schools as the Architects of the Mexican Race in Depression-Era Wyoming
}

\author{
Gonzalo Guzmán \\ Email: gguzman1@colgate.edu
}

\begin{abstract}
This article examines the development of racially segregated Mexican rooms and Mexican schools in Wyoming during the Depression era. Working in concert with New Deal legislation, the segregation of Mexican children - regardless of US citizenship-in Wyoming was not just a matter of social practice and local custom, it became an expression of increased state and federal power that mirrored Jim Crow laws. Wyoming was not alone. The segregation of Mexicans also occurred in neighboring Colorado, Montana, and Nebraska. This article also discusses how, ultimately, public schools and schooling finalized the codification and institutionalization of Mexicans as a race of their own. In Wyoming, schools were the architects of the Mexican race. Furthermore, this unexplored area demonstrates that the segregation of Mexican children was not just a Southwest phenomenon but encompassed almost all of the US West.
\end{abstract}

Keywords: Mexican American education; public schools; racialization; segregation; Great Depression; Wyoming

\section{Introduction}

Things change you know. They really change from what they used to be. I don't know why because when I was in school, I remember Mexicans and White all mixed together, you know in the lower grades.

$$
\text { -Julia Leyva, Worland, Wyoming }{ }^{1}
$$

On September 11, 1956, a group of White parents-called the Committee of Citizens - attended a school board meeting in the small agricultural town of Worland, Wyoming. They were protesting the discrimination their children were experiencing in being forced to transfer to the recently desegregated West Side

\footnotetext{
${ }^{1}$ Julia Leyva interview, transcribed Oct. 4, 1983, Oral History Project, Washakie County Museum and Cultural Center, Worland, Wyoming. Unfortunately, the majority of primary sources used in this article come from White people's perspective, and primary sources on a similar scale from the Mexican community in the Wyoming localities of this study were not available. I hope to find these kinds of materials in the future and that this article assists in bringing those Mexican voices to the forefront.
} 
School, known locally as the "Mexican" or "Spanish school." 2 Edith Scollard, one of the parents whose children were going to be placed in a classroom with majority Spanish children, protested against "her children integrating with the Spanish element in the school system." ${ }^{3}$ At the meeting, however, the school's principal read the school census out loud to reveal that out of a classroom of thirty-eight students, only four were Spanish-speaking or children of Mexican descent. Scollard was informed that the school board could not promise that her child would not be transferred and that the attitude of the board had always been one of seeking equality throughout the school system. The meeting recorder made note of the exchange, writing that "Mrs. Scollard's issue was racial and one against integration." 4 The incident at Worland was not an isolated affair but signaled the collapse of a Jim Crow-like school system in Wyoming-officially nicknamed the Equality State-that targeted Mexican children during the Great Depression. ${ }^{5}$

The educational experiences of Mexicans have always been tied to their racial status and identities. As historians of the Mexican experience in the US West have documented, although legally White, Mexicans were considered non-White and treated as a "race of their own." This racial logic in various places in the US was unclear, and some attempted to segregate Mexican children on grounds they had "black blood," were racially mixed, or were Indigenous. ${ }^{7}$ In other cases, Mexicans were declared part of the White race to dismiss Mexican parents' challenges to school segregation. ${ }^{8}$

\footnotetext{
${ }^{2}$ The sources in this article use several terms to describe individuals of Mexican descent, ethnicity, or origin, including Mexican, Mexican American, Spanish, Spanish American, and Hispano. The majority of Mexicans in Wyoming schools were US-born, but for the sake of clarity, the terms Mexican American and Mexican are used interchangeably, unless otherwise noted, regardless of citizenship status.

${ }^{3}$ Minutes, Sept. 11, 1956, Worland School District Record of Proceedings, Minutes of Annual Meetings, School District No. 6, Worland, Wyoming, Washakie County Schools Records, Wyoming State Archives, Cheyenne, Wyoming (hereafter cited as WCSR). For more on the racialization of the Spanish language in the US, see Rosina Lozano, An American Language: The History of Spanish in the United States (Oakland: University of California Press, 2018); and Jonathan Rosa, Looking Like a Language, Sounding Like a Race: Raciolinguistic Ideologies and Learning of Latinidad (Oxford: Oxford University Press, 2019).

${ }^{4}$ Minutes, Sept. 11, 1956, WCSR, 2.

${ }^{5}$ Scholars have called the Jim Crow system that targeted Mexicans in the Southwest "Jamie Crow." See Albert M. Camarillo, "Navigating Segregated Life in America's Racial Borderhoods, 1910s-1950s," The Journal of American History 100, no. 3 (Dec. 2013), 649-50.

${ }^{6}$ See Laura E. Gómez, Manifest Destinies: The Making of the Mexican American Race, 2nd ed. (New York: New York University Press, 2018); Monica Muñoz Martinez, The Injustice Never Leaves You: Anti-Mexican Violence in Texas (Cambridge, MA: Harvard University Press, 2018); Martha Menchaca, Recovering History, Constructing Race: The Indian, Black and White Roots of Mexican Americans (Austin: University of Texas Press, 2001); and Natalia Molina, How Race Is Made in America: Immigration, Citizenship, and the Historical Power of Racial Scripts (Berkeley: University of California Press, 2014).

${ }^{7}$ Rubén Donato and Jarrod Hanson, “'Porque Tenían Sangre de 'Negros': The Exclusion of Mexican Children from a Louisiana School, 1915-1916," Association of Mexican American Educators Journal 11, no. 1 (2017), 125-45; and Mike Madrid, "The Lemon Grove Desegregation Case: A Matter of Neglected History," in Latino Civil Rights in Education: La Luche Sigue, ed. Anaida Colón-Muñiz and Magaly Lavadenz (New York: Routledge, 2016), 47-57.

${ }^{8}$ Legal scholar and historian Ariela Gross defined this strategy as a "Caucasian Cloak." See Ariela Gross, What Blood Won't Tell: A History of Race on Trial in America (Cambridge, MA: Harvard University Press, 2009), 253-93.
} 


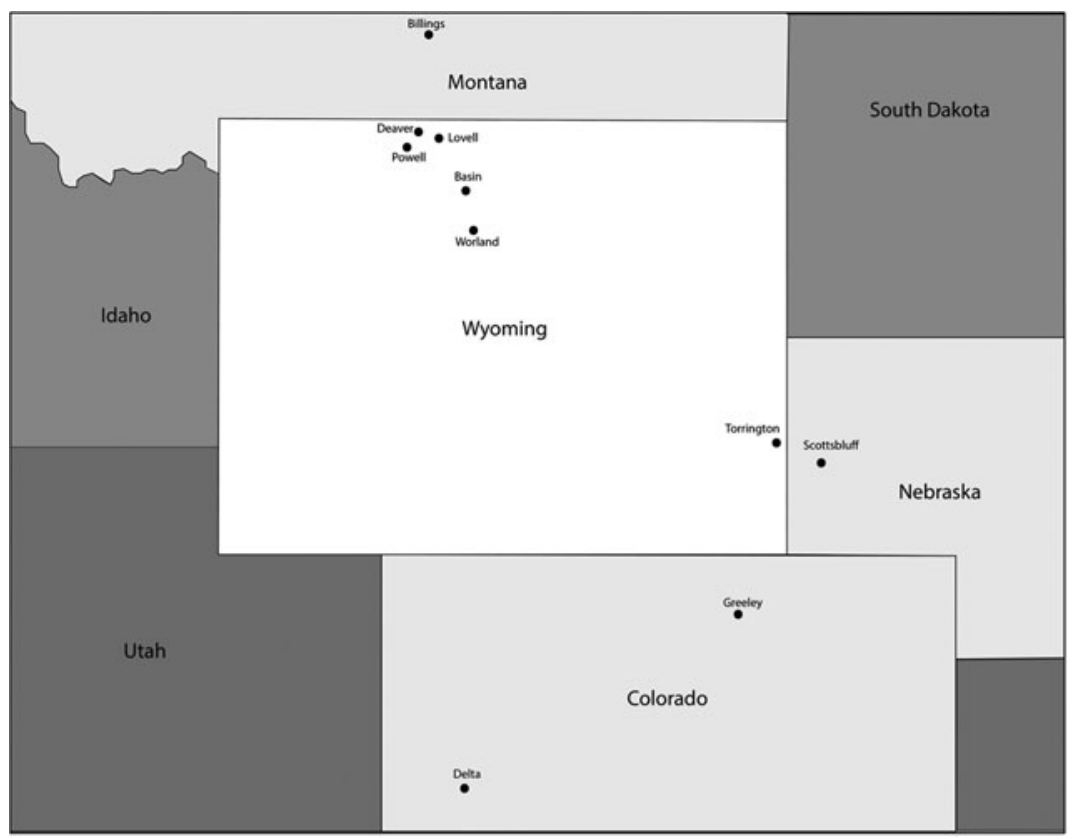

Figure 1. Documented locations of segregated Mexican rooms and schools in the upper Mountain West. Image created by author.

One vivid example is a 1914 desegregation case in Colorado where Mexican parents challenged school segregation on grounds that they were of the "Mexican race," and being forced to attend the city's segregated Mexican school was in violation of the state's constitution that barred discrimination in public schools on the basis of race or color. ${ }^{9}$ The White school board countered that no violation occurred because Mexican children were "white children of the Caucasian race."10 Only in 1930 did the US Census identify Mexicans as a separate racial category; still, no state or federal laws allowed for the racial segregation of Mexican children in schools. In 1940, the US Census eliminated the Mexican race category, and once again Mexicans were identified as part of the White race. ${ }^{11}$ With outright confusion on the racial status of Mexicans and no laws permitting their segregation, schools played a distinct role in dictating the place of Mexicans in racial hierarchies. ${ }^{12}$ This especially holds true in Wyoming, where in

\footnotetext{
${ }^{9}$ Rubén Donato, Gonzalo Guzmán, and Jarrod Hanson, "Francisco Maestas et al. v. George H. Shone et al: Mexican American Resistance to School Segregation in the Hispano Homeland, 1912-1914," Journal of Latinos and Education 16, no. 1 (2017), 6.

${ }^{10}$ Donato, Guzmán, and Hanson, "Francisco Maestas," 8.

${ }^{11}$ Paul Schor, Counting Americans: How the US Census Classified the Nation (Oxford: Oxford University Press, 2017), 214-17.

${ }^{12}$ Other scholars have also noted the distinct role schools played in placing Mexicans in US racial hierarchies. For examples, see David G. García, Strategies of Segregation: Race, Residence, and the Struggle for Educational Equality (Oakland: University of California Press, 2018), 2, 55-56; Clif Stratton, Education for Empire: American Schools, Race, and the Paths of Good Citizenship (Oakland: University of California Press, 2016), 3-4, 13-15. For how schools were also used to disrupt and contest racial hierarchies, see
} 
many cases schools were the only institutions that could make and hold the color line. ${ }^{13}$

Mexican American educational history in Wyoming is virtually nonexistent. ${ }^{14}$ This scholarly neglect signifies a larger omission of the role public schools played in race formation in the state and the US West. ${ }^{15}$ The omission has led to scholarly contradictions and a prevailing myth that despite having a permissive segregation law (allowed by not legally required), segregated schools based on race were never established in Wyoming. ${ }^{16}$ This myth has deviated little from similar views promoted by Wyoming officials in the late nineteenth century. For instance, during congressional testimony in 1889 regarding Wyoming's statehood, the Wyoming territorial representative-Joseph Maull Carey-declared to Congress that in Wyoming, "there is no question of race. Our first legislature. . . opened the doors of her public schools to blacks as well as to the white children." ${ }^{17}$ When pressed further if race distinction existed in Wyoming schools, Carey simply stated, "No." ${ }^{18}$ Yet this myth is just that, a myth. Wyoming was home to failed and successful attempts to segregate Asian, Black, and Indigenous children. ${ }^{19}$ However, no group experienced racial

Philis M. Barragán Goetz, Reading, Writing, and Revolution: Escuelitas and the Emergence of a Mexican American Identity in Texas (Austin: University of Texas Press, 2020); Victoria-María MacDonald and Gonzalo Guzmán, "Revolution and World War I Civil Rights?: Transnational Relations and Mexican Consul Records in Mexican American Educational History, 1910-1929," Education's Histories 4, no. 5 (Dec. 2017), 1-44, https://scholarworks.umt.edu/eduhist/vol4/iss1/5/; Guadalupe San Miguel Jr., Chicana/o Struggles for Education: Activism in the Community (College Station: Texas A\&M University Press, 2013); and Maribel Santiago, Cati V. de los Ríos, and Kris Gutiérrez, "Historicizing Latinx Civic Agency and Contemporary Lived Civics," in Educating for Civic Reasoning \& Discourse, ed. Carol D. Lee, Gregory White, and Dian Dong (Washington, DC: National Academy of Education, 2021), 206-24, https://naeducation.org/wp-content/uploads/2021/04/NAEd-Educating-for-Civic-Reasoning-and-Discourse.pdf.

${ }^{13}$ For the lack of social history on race in Wyoming before the 1980s, see Eugene B. Berwanger, "The Absurd and the Spectacular: The Historiography of the Plains-Mountain States: Colorado, Montana, Wyoming," Pacific Historical Review 50, no. 4 (Nov. 1981), 473.

${ }^{14}$ For an exception, see Gonzalo Guzmán, "Education for a New Race: White Schools, Child Labor, and Creating the Mexican in the Intermountain West, 1917-1943" (PhD diss., University of Washington, 2018).

${ }^{15}$ For a historiographical essay on the matter, see Nancy Beadie et al., "Gateways to the West, Part II: Education and the Making of Race, Place, and Culture in the West," History of Education Quarterly 57, no. 1 (Feb. 2017), 94-126. See also Jason E. Pierce, Making the White Man's West: Whiteness and the Creation of the American West (Boulder: University of Colorado Press, 2016); and Vicki I. Ruiz, "Tapestries of Resistance: Episodes of School Segregation and Desegregation in the Western United States," in From the Grassroots to the Supreme Court: Brown v. Board of Education and American Democracy, ed. Peter F. Lau (Durham, NC: Duke University Press, 2004), 44-67.

${ }^{16}$ Reagan Joy Kaufman, "Discrimination in the 'Equality State': Black-White Relations in Wyoming History," Annals of Wyoming 77, no. 1 (Winter 2005), 19-20; Patricia Reid-Merritt, ed., A State-by-State History of Race and Racism in the United States, vol. 2, Montana-Wyoming (Santa Barbara, CA: Greenwood, 2019), 975; and Velma Linford, interview by Richard Laughlin, Jan. 31, 1973, interview OH 0123, Richard Laughlin Oral History Collection, Wyoming State Archives, Cheyenne, Wyoming.

${ }^{17}$ United States Congress, Admission of Arizona, Idaho, and Wyoming into the Union, H. R. Rep. No. 4053, 50th Cong., 2nd Sess., 1889 (Washington, DC: Government Printing Office, 1889), 39.

${ }^{18}$ United States Congress, Admission of Arizona, Idaho, and Wyoming, 39.

${ }^{19}$ Clayton B. Fraser, Mary M. Humstone, and Rheba Massey, Places of Learning: Historical Context of Schools in Wyoming (Cheyenne: Wyoming State Historic Preservation Office, 2010), 70, 171, 184; Martha Louise Hipp, Sovereign Schools: How Shoshones and Arapahos Created a High School on the Wind River Reservation (Lincoln: University of Nebraska Press, 2019); and Esther Burnett Horne and Sally McBeth, Essie's Story: The Life and Legacy of a Shoshone Teacher (Lincoln: University of Nebraska Press, 1998). 
segregation in public schools on such a scale than the Mexican American and Mexican population residing in the state. By the dawn of World War II, segregated educational tracks, classrooms, and schools based on race were the experience of many Mexican American and Mexican children in Wyoming, mirroring the Jim Crow experiences of the Southwest. ${ }^{20}$

In this article, I examine the development and expansion of racial segregation targeting children of Mexican descent in Wyoming during the Great Depression. In the 1920s segregation of Mexican children was a rarity. But it became commonplace in the 1930s. This study illuminates the central role of schools in the racial formation of Mexicans as a separate and distinct race. ${ }^{21}$ Wyoming developed multiple segregation strategies for Mexican children, ranging from separate tracks and separate rooms to the establishment of separate schools. ${ }^{22}$ Wyoming, in fact, received federal funds vis-à-vis the New Deal for the sole purpose of segregating Mexican children. New Deal funding and federal legislation such as the Sugar Act in 1934 and its subsequent revision in 1937 were essential to the buildup of structural discrimination targeting Mexicans in the state. Historian David G. García in his study of Oxnard, California, found that local elite and everyday White peoplecivic and business leaders, teachers, parents, homeowners-were central in the race and school segregation of the resident Mexican community. García named this group the "white architects of Mexican American education." ${ }^{23}$ Wyoming expanded this definition by demonstrating how European immigrants such as German Russians, as well as state and federal agencies, were part of this "white architects" group.

This study of Wyoming analyzes segregated schooling from a racial relational lens. Historian Natalia Molina aptly argues that to understand the construction of the racial category of "Mexican" we must understand its relationship to other racialized groups. ${ }^{24}$ The areas in Wyoming where segregation developed were not governed by racialized binaries but instead were multiracial and ethnic environments. The sugar beet industry recruited Filipino, German Russian, Japanese, and Mexican agricultural labor to the state. ${ }^{25}$ However, it was the relationship between Mexicans and Eastern European immigrants, the German Russians, that would be the most

\footnotetext{
${ }^{20}$ The segregated and racist landscape that developed in Wyoming shares striking similarities to those in California, Colorado, and Texas in the same era. For examples, see Rubén Donato, Mexicans and Hispanos in Colorado Schools and Communities, 1920-1960 (Albany: State University of New York Press, 2007); Neil Foley, The White Scourge: Mexicans, Blacks, and Poor Whites in Texas Cotton Culture (Berkeley: University of California Press, 1999); García, Strategies of Segregation; Matt Garcia, A World of Its Own: Race, Labor, and Citrus in the Making of Greater Los Angeles, 1900-1970 (Chapel Hill: University of North Carolina Press, 2001); and Martha Menchaca, The Mexican Outsiders: A Community History of Marginalization and Discrimination in California (Austin: University of Texas Press, 1995).

${ }^{21}$ Sociologists Michael Omi and Howard Winant define racial formation as "the sociohistorical process by which racial identities are created, lived out, transformed, and destroyed." This article abides by this definition. See Michael Omi and Howard Winant, Racial Formation in the United States from the 1960s to the 1980s, 3rd ed. (New York: Routledge, 2014), 109.

${ }^{22}$ For a similar process in Oxnard, California, see García, Strategies of Segregation, 2.

${ }^{23}$ García, Strategies of Segregation, 3-4, 13.

${ }^{24}$ Natalia Molina, "Examining Chicana/o History through a Relational Lens," in Relational Formations of Race: Theory, Method, and Practice, ed. Natalia Molina, Daniel Martinez HoSang, and Ramón A. Gutiérrez (Oakland: University of California Press, 2019), 47.

25“"The Advent of the Russian-Germans," Powell (WY) Tribune, Feb. 18, 1926, 2; and "Beet Sugar a Labor Problem," Worland (WY) Grit, Feb. 5, 1925, 2.
} 
pronounced, especially in schooling. ${ }^{26}$ Until the Great Depression, White school and state officials saw Mexican and German Russian children as part of the same "educational problem." In fact, when comparing the two groups of students academically and attendance-wise, one superintendent noted that "of the two classes, the Mexicans are the better." 27 It would not be until 1936 that Mexicans in said community would be sent to a segregated school and this would be duplicated in some fashion throughout Wyoming. Thus, one cannot talk about the segregation of the Mexican child on the one hand without acknowledging the integration of the German Russian on the other. $^{28}$ Emboldened by the New Deal and rising anti-Mexican sentiment by White and German Russian parents, schools became the architects of race, with educators such as teachers, principals, and superintendents becoming the final actors in the race-formation process that distinguished Mexicans from all other racial groups. ${ }^{29}$ In Wyoming, public schools finalized the institutionalization of Mexicans as non-White and thus created the "Mexican race."

\section{A Brief History of Mexican Children in Wyoming Schools}

Wyoming's Mexican presence dates back to territorial days of the late nineteenth century, though the Mexican population became noticeably permanent in the twentieth century. $^{30}$ The number of Mexicans grew quickly, from 2,051 in 1920 to 7,174 in 1930, making Wyoming the state with the seventh highest percentage of Mexicans in the US. ${ }^{31}$ The majority of the Mexican population settlement was a consequence of the state's expanding sugar beet industry, which was dependent on migrant and family contract labor. Mexicans soon became invaluable to Wyoming's agricultural economy, even prompting Wyoming senators and farmers to go before Congress in 1928 to protest restrictive immigration legislation. ${ }^{32}$ In compelling testimony by

\footnotetext{
${ }^{26}$ Other scholars have noted German Russian and Mexican differentiation, but their relationship in schooling is largely absent. See Meggan L. Bilotte, "Becoming Native: Family Labor and Belonging in the Sugar Beet Fields of Northern Colorado, 1900-1969" (PhD diss., University of Wisconsin, 2020), 28, 103-4.

${ }^{27}$ C. H. Studebaker to Grace Raymond Hebard, Nov. 13, 1929, folder 1, box 3, Grace Raymond Hebard Papers, American Heritage Center, Laramie, Wyoming (hereafter cited as GRHP).

${ }^{28}$ Although not an educational history, a study by Katherine Benton-Cohen covers a similar relationship that developed between Mexicans and Southern and Eastern European immigrants in Cochise County, Arizona. See Katherine Benton-Cohen, Borderline Americans: Racial Division and Labor War in the Arizona Borderlands (Cambridge, MA: Harvard University Press, 2009).

${ }^{29}$ Historian David Torres-Rouff also declared segregated schools as the "architects of race" in his study of southern California. See David Torres-Rouff, "Becoming Mexican: Segregated Schools and Social Scientists in Southern California, 1913-1946," Southern California Quarterly 94, no. 1 (Spring 2012), 93-94.

30"Mexican Immigration to Wyoming," notes by Lawrence Cardoso, folder 6, box 9, Lawrence Cardoso Papers, American Heritage Center, Laramie, Wyoming (hereafter cited as LCP); and Antonio Ríos-Bustamante, "Wyoming's Mexican Hispanic History," Annals of Wyoming 73, no. 2 (Spring 2001), $2-9$.

${ }^{31}$ Elizabeth Broadbent, "The Distributions of Mexican Populations in the U.S” (PhD diss., University of Chicago, 1941), 171.

${ }^{32}$ For an excellent discussion of immigration hearings pertaining to the sugar beet industry and Mexican labor, see Kathleen Mapes, Sweet Tyranny: Migrant Labor, Industrial Agriculture, and Imperial Politics (Chicago: University of Illinois Press, 2009), 143-65.
} 
John B. Kendrick, senator and former governor of Wyoming, he claimed, "I say to you in all sincerity that if you do prevent us from getting that Mexican labor you are going to destroy the beet sugar industry of my State." ${ }^{33}$ The former governor understood that Mexican labor was central to the state's economy.

The fact that the Mexican laborers brought their children to Wyoming influenced the way sugar beet companies went about recruiting and retaining them. ${ }^{34} \mathrm{~A}$ distinct component of the sugar beet industry of the Mountain States-Colorado, Montana, Nebraska, and Wyoming-was the massive Mexican colonization project focused on family recruitment and the creation of company colonies that housed families during the winter. ${ }^{35}$ This strategy reached its apex during the latter 1920 s, and by 1929 , the colonization endeavor in Wyoming created Mexican settlements in areas such as the Big Horn Basin, the North Platte Valley, Sheridan, and Wheatland. ${ }^{36}$ As a consequence of the family labor practice and colonization schemes, the education of farm laborers' children developed into a pressing issue where Mexican colonies were established in Wyoming. At first, these students, along with the children of other laborers, attended school with the children of local White Americans. However, congressional committee hearing testimony on immigration restrictions called into question the viability of mixing Mexican and White children. At one point, White Wyomingites testified that they had no issues with integration, and one farmer-Jess Crosby-from Cowley testified that "the white people accept [the Mexican children] alright." 37

\footnotetext{
${ }^{33}$ S. 1296, a Bill to Amend the Immigration Act of 1924; S. 1437, a Bill to Subject Certain Immigrants, Born in Countries of the Western Hemisphere, to the Quota under the Immigration Laws; S. 3019, a Bill to Amend the Immigration Laws and for Other Purposes, Hearings Before the Committee on Immigration, 70th Cong., 1st sess. (testimony of Senator John B. Kendrick, representing the State of Wyoming) (Washington DC: US Government Printing Office, 1928), 72.

${ }^{34}$ For how sugar beet companies used public schools as a recruitment strategy, see Escuela de Niños en Una de Las Colonias de los Trabajadores, Beet Labor Film, c. 1924, black-and-white silent film, section 2, 1:00-1:58, Great Western Sugar Digital Collection, Colorado State University, Fort Collins, CO, http://hdl. handle.net/10217/31600.

${ }^{35}$ This is not to say that sugar beet companies did not have similar strategies elsewhere, but the focus was on the Mountain States. See Frank P. Barajas, Curious Unions: Mexican American Workers and Resistance in Oxnard, California, 1898-1961 (Lincoln: University of Nebraska Press, 2012); Donato, Mexicans and Hispanos; Sarah Deutsch, No Separate Refuge: Culture, Class, and Gender on the Anglo-Hispanic in the American Southwest, 1880-1940 (New York: Oxford University Press, 1989); April Merleaux, Sugar and Civilization: American Empire and the Cultural Politics of Sweetness (Chapel Hill: University of North Carolina Press, 2015); Jim Norris, North for the Harvest: Mexican Workers, Growers, and the Sugar Beet Industry (Minneapolis: Minnesota Historical Society, 2009); and Dennis Nodín Valdés, "Settlers, Sojourners, and Proletarians: Social Formation in the Great Plains Sugar Beet Industry, 1890-1940," Great Plains Quarterly 10, no. 2 (Spring 1990), 110-23.

${ }^{36}$ H.R. 6465, H.R. 7358, H.R. 10955, H.R. 11687, Immigration from Counties of the Western Hemisphere, Hearings Before the House Committee on Immigration and Naturalization, 70th Cong., 614-15 (1928) (testimony of C. V. Maddux, representing the Great Western Sugar Company); Fred Holmes, Labor Superintendent, Holly Sugar Company, interview by Paul S. Taylor, folder 25, carton 11, Paul S. Taylor Papers, Bancroft Library, UC Berkeley, Berkeley, California (hereafter cited as PSTP); and Augustin Redwine, "Lovell's Mexican Colony," Annals of Wyoming 51, no. 2 (Fall 1979), 26-35.

${ }^{37}$ H.R. 6465, H.R. 7358, H.R. 10955, H.R. 11687, Immigration from the Counties of the Western Hemisphere, Hearings Before the House Committee on Immigration and Naturalization, 70th Cong., 340 (1928) (testimony of Jess Crosby, representing the State of Wyoming).
} 
The testimony from the Cowley farmer was not just appeasement to antiimmigration legislators, but seemed to describe the experience of most Mexican children in the sugar beet communities in Wyoming before the Great Depression. The schooling problem produced by the sugar beet industry, however, was on the radar of school officials as early as 1922 when Wyoming passed its first child labor laws. ${ }^{38}$ And as the beet industry expanded throughout the state, so did the educational "problem." It included irregular school attendance from child laborers, especially those working in the beet fields. ${ }^{39}$ By 1929, responding to the education needs of children working in the sugar beet fields, Wyoming's governor, Frank C. Emerson, ordered the state's Child Labor and Welfare Committee to find a solution to the irregular school attendance of "beet children."

Between 1929 and 1931, Wyoming school and state officials launched an intrastate campaign to develop an educational policy for its beet children, a policy that centered on their labor class status and not their race and ethnicity. The educational campaign consumed the governor-appointed Child Labor and Welfare Committee led by Grace Raymond Hebard, a University of Wyoming professor and Americanization advocate. ${ }^{40}$ Hebard and the committee focused on creating an educational policy that allowed beet children to "catch-up" and integrate with White American children outside of the sugar beet industry. ${ }^{41}$ As Hebard noted, "In this way, directly or indirectly, the two sets of children come into contact which helps in an educational democracy." 42 Here the committee embraced a view of the Mexican and beet child as an "immigrant" child worthy of Americanization at a time when similar movements almost exclusively focused on European immigrants. ${ }^{43}$ The placing of Mexican children in White schools as a form of Americanization was different from other historical accounts that saw segregation in controlled environments where they were

\footnotetext{
${ }^{38}$ Wyoming passed its compulsory school law in 1907, and as early as 1922 Wyoming school officials recognized the child labor problem in the beet fields. See Fraser, Humstone, and Massey, Places of Learning, 56; and James R. Coxen, Wyoming State Director for Vocational Education, to Hebard, Dec. 30, 1922, folder 25, box 2, GRHP.

39"Wyoming Comes to the Fore," American Child 5, no. 5 (May 1923), 6; "How Schools and Farmers Work Together in Wyoming," American Child 6, no. 3 (March 1924), 7; Lewis C. Tidball, Jr. to Hebard, March 19, 1924, folder 26, box 2, GRHP; "Children Exploited in the Beet Sugar Fields," Casper (WY) Herald, Feb. 4, 1922, 1.

${ }^{40}$ For an in-depth discussion of Hebard's Americanization efforts and overall education career, see Frank Van Nuys, Americanizing the West: Race, Immigrants, and Citizenship, 1890-1930 (Lawrence: University Press of Kansas, 2002).

${ }^{41}$ This educational policy is mentioned repeatedly during the education campaign but was especially emphasized when Hebard corresponded with Thomas F. Mahony of the Mexican Welfare Committee in Colorado. See Hebard to Thomas F. Mahony, Jan. 18, 1930, folder 2, box 3, GRHP.

${ }^{42}$ Hebard to E. D. Morgan, Wyoming Commissioner of Education, Feb. 15, 1930, folder 1, box 3, GRHP.

${ }^{43}$ For more about Americanization education targeting Mexicans and others, see Lawrence A. Cardoso, "Nativism in Wyoming 1868-1930: Changing Perceptions of Foreign Immigrants," Annals of Wyoming 58, no. 1 (Spring 1986), 27-28; René Galindo, "The Nativist Legacy of the Americanization Era in the Education of Mexican Immigrant Students," Educational Studies 47, no. 4 (2011), 323-46; Zevi Gutfreund, Speaking American: Language Education and Citizenship in Twentieth-Century Los Angeles (Norman: University of Oklahoma Press, 2019); and Jeffrey Mirel, Patriotic Pluralism: Americanization Education and European Immigrants (Cambridge, MA: Harvard University Press, 2010).
} 
Americanized and taught English. ${ }^{44}$ In fact, the issue of English language acquisition was not discussed in Wyoming until after segregation was in place. ${ }^{45}$

Hebard's discussion with the superintendent of Worland schools, C. H. Studebaker, is by far the most vivid indication that educational policy for students of Mexican descent at that time was focused on a form of inclusion rather than racial exclusion. Studebaker and Worland school officials objected to any form of segregation of Mexican, German Russian, or Japanese students. He objected to segregation on economic grounds but most of all believed segregated schools conflicted with Americanization. In his words, "There has been talk here several times of segregating these students [Mexicans], but we school people have always opposed it, first because it would increase our expense, which we can ill afford, and that we feel we would be doing a poor job of Americanizing them in that way." "46 In fact, Studebaker's position against segregating Mexicans was also informed by his opinion that Mexicans were academically better students than other beet children, particularly German Russians:

What I have said about the Mexicans applies also to the Russian-German element we have here. Of the two classes though, the Mexicans are the better. Once the Mexican children start school they go through to the end of the year without trouble, while the others are hard to handle, and very irregular in attendance... . We have several Mexican students in the upper grades who are very good students. At present there is a part Mexican girl in High School, I believe in the senior class, who is really a brilliant girl. ${ }^{47}$

As Hebard and the committee presented their plan to educationally mainstream both groups throughout the state, they ran into pushback from a source they had not anticipated, German Russian parents. Hebard acknowledged, "We are finding practically no objection from the Mexican parents, but we find objection from the Russians and Germans and hence we feel they are the ones who need it the most." ${ }^{48}$ Unlike Mexican parents, German Russian parents objected to any educational services or interventions that conflicted with their children working on familyowned farms. Studies of other states found that unlike with Mexican families, it was the German Russian families who kept more of their school-age children in the sugar

\footnotetext{
${ }^{44}$ Gilbert G. González, Chicano Education in the Era of Segregation, 2nd ed., (Denton: University of North Texas Press, 2013), xiv, 38.

${ }^{45}$ Historians of Mexican American education have well documented how pedagogical segregation was a legal cloak for racial segregation that appeared in many desegregation cases, such as Romo v. Laird (1925), Independent School District v. Salvatierra (1930), and other disputes. See Laura K. Muñoz, "Romo v. Laird: Mexican American School Segregation and the Politics of Belonging in Arizona," Western Legal History 26, nos. 1-2 (2013), 97-132; Rubén Donato and Jarrod Hanson, “Legally White, Socially 'Mexican': The Politics of De Jure and De Facto Segregation in the American Southwest," Harvard Educational Review 82, no. 2 (Summer 2012), 212-15; and Richard Valencia, Chicano Students and the Courts: The Mexican American Legal Struggle for Educational Equality (New York: New York University Press, 2008), 7-79.

${ }^{46}$ Studebaker to Hebard, Dec. 11, 1929, folder 1, box 3, GRHP.

${ }^{47}$ Studebaker to Hebard, Nov. 13, 1929, folder 1, box 3, GRHP.

${ }^{48}$ Hebard to W. E. Baker, Feb. 8, 1930, folder 2, box 3, GRHP.
} 


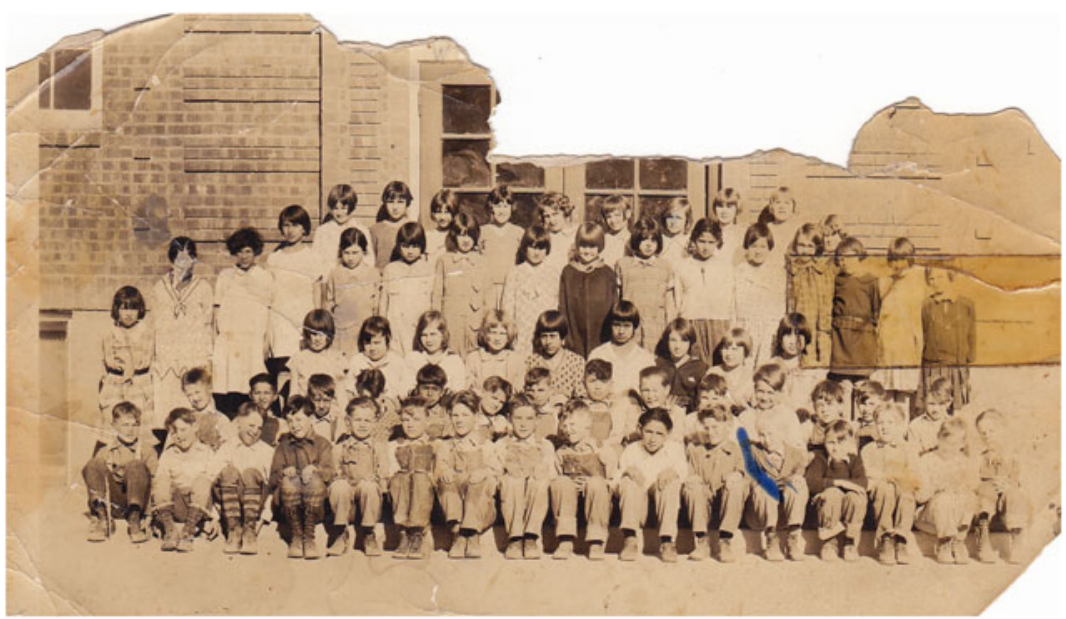

Figure 2. German Russian, Japanese, Mexican, and White children in pre-segregation elementary classroom photo in Worland, 1932. Image courtesy of Joe Ramirez.

beet fields, partially because many were tenant farmers or farm owners themselves, which was not the case for Mexicans in the industry. ${ }^{49}$

The relationship between German Russians and Mexicans was central in defining whiteness in the sugar beet communities of Wyoming. For instance, Paul S. Taylor, noted economist and pioneering Mexican labor researcher, noted that although European, German Russians were not considered fully White in sugar beet communities:

Another problem arises in the use of the term "white." It is a mistake to think that because white and Negroes are used as opposing terms, that "white" always refers to color. In northeastern Colorado one encounters the strange popular usage which in its terminology divides the community into three: "whites," meaning English-speaking Americans or Americanized Europeans; "Mexicans" meaning indiscriminately Mexicans from Old Mexico and Spanish Americans; and "German Russians" ("Russians" or "Rooshians"), who are still a large and sufficiently unassimilated group not to be covered by the term "white."

In Wyoming, German Russians specifically identified themselves in relation to Mexicans. For instance in 1919, German Russian sugar beet workers refused to share a passenger coach with Mexican workers in Lingle, causing such a protest that representatives of the Great Western Sugar Company intervened. ${ }^{51}$ Only after separate accommodations in town were made for the German Russians did the

\footnotetext{
${ }^{49}$ Deutsch, No Separate Refuge, 124; “Beet Field Workers," Alliance (NE) Herald, April 22, 1922; Henry Schaechterle to Henry A. Wallace, US Secretary of Agriculture, Sept. 22, 1937, Child Labor: Sugar Beets 1935-1937 folder, box 2, William T. Ham Papers, American Heritage Center, Laramie, Wyoming.

${ }^{50}$ Paul S. Taylor, "Mexican Labor in the United States Valley of the South Platte Colorado," in Mexican Labor in the United States, vol. 1 (Berkeley: University of California Press, 1930), 104.

${ }^{51}$ Christian Welsch, "A Voice from the Past: A German-Russian Life," Journal of the American Historical Society of Germans from Russia 4, no. 1 (Spring 1981), 52.
} 
protest end, while the Mexicans remained in the railroad car. ${ }^{52}$ In Worland, Mexican Americans noted that it was the German Russians who made it a priority for their children to not to play with Mexican children. One woman commented, "Well, when I went to school some of the white kids, most of your Russians, they would tell their kids you know you can't play with them and Mexicans were you know, you just didn't hang around with them." ${ }^{33}$ However, German Russian families also linked their educational fates to the presence of Mexicans in the sugar beet industry, one German-Russian, Paulina Hahn, acknowledged, "Well, in one way it [the increased use of Mexican labor] was the best thing that ever happened to German Russians, because their children were in school year round." 54 In other words, "school was the place German-Russians could be converted from German-Russian immigrants into American citizens." 55 Or where German Russians could become White.

Although the Child Labor and Welfare Committee found racial integration to be the norm for Mexican children, it also found that German Russian families increasingly looked to schools to separate themselves from Mexicans. In the summer of 1929, the school board in Torrington, Wyoming, decided to build a new school, the South Torrington School, in its sugar beet factory district. ${ }^{56}$ The new school was built to meet the special educational needs of beet children, specifically those from Mexican and German Russian families. ${ }^{57}$ Before this time, beet children, regardless of race, nationality, or labor status, had attended the city school with all children in a desegregated setting. ${ }^{58}$ Usually beet children were placed in designated classrooms, "opportunity rooms"-designed to integrate them fully into Torrington schools. However, once the new school was built, it was a source of racial tension. Fighting was a constant problem in the school and German Russian parents objected so strenuously to their children mixing with the Mexicans that they withdrew their children from the two-room school. ${ }^{59}$ The German Russian parents threatened to

\footnotetext{
${ }^{52}$ Welsch, "Voice from the Past," 52.

${ }^{53}$ Helen Smotherman interview by Mary Ellen Coca, Worland, Wyoming, March 28, 1983, booklet 1, box 15, Lawrence Cardoso Papers, American Heritage Center, Laramie, Wyoming (hereafter cited as LCP).

${ }^{54}$ Chad Delano Shaw, "Twice Separated without a State: German-Russians in Weld County, 1900-1920" (master's thesis, University of Northern Colorado, 2006), 101.

${ }^{55}$ Shaw, "Twice Separated without a State," 92, 96. Also see, David B. Tyack, ed., Turning Points in American Educational History (Waltham, MA: Blaisdell Publishing Company, 1967), 228.

56“Secure Contract for Erecting School Building," Torrington (WY) Telegram, July 18, 1929, 1; and "Schools Open on Sept. 9th-Corps of Teachers Selected," Torrington (WY) Telegram, Aug. 15, $1929,1$.

${ }^{57}$ For more on the educational and racial experiences of German Russians, see Billotte, "Becoming Native," 66-108; Donald Hodgson and Vivien Hills, "Dream and Fulfillment: Germans in Wyoming," in Peopling the High Plains: Wyoming's European Heritage, ed. Gordon Olaf Hendrickson (Cheyenne: Wyoming State Archives, 1977), 35-66; Don Hodgson, “The Other Germans in Wyoming” Annals of Wyoming 63, no. 4 (Autumn 1991), 145-49; Randall C. Teeuwen, "Public Rural Education and the Americanization of the Germans from Russia in Colorado: 1900-1930" (master's thesis, Colorado State University, 1993); and Kathleen Legg, “That Young Girl Should Be in School, Not Out Drilling Wheat! The Germans from Russia, Race, and Americanization in Northeastern Colorado," seminar paper for HY 640 State and Local History Research Seminar, Colorado State University, December 13, 2005.

${ }^{58}$ A. H. Dixon, Superintendent of Public Schools, Goshen County, Wyoming, to Grace Raymond Hebard, Nov. 29, 1929, GRHP.

${ }^{59}$ For more on the German Russian racial animosity toward Mexicans, see Smotherman, interview; A. H. Dixon, interview notes, April 28, 1931, folder 2, box 3, GRHP; Duvan Lujan, interview by Greg
} 


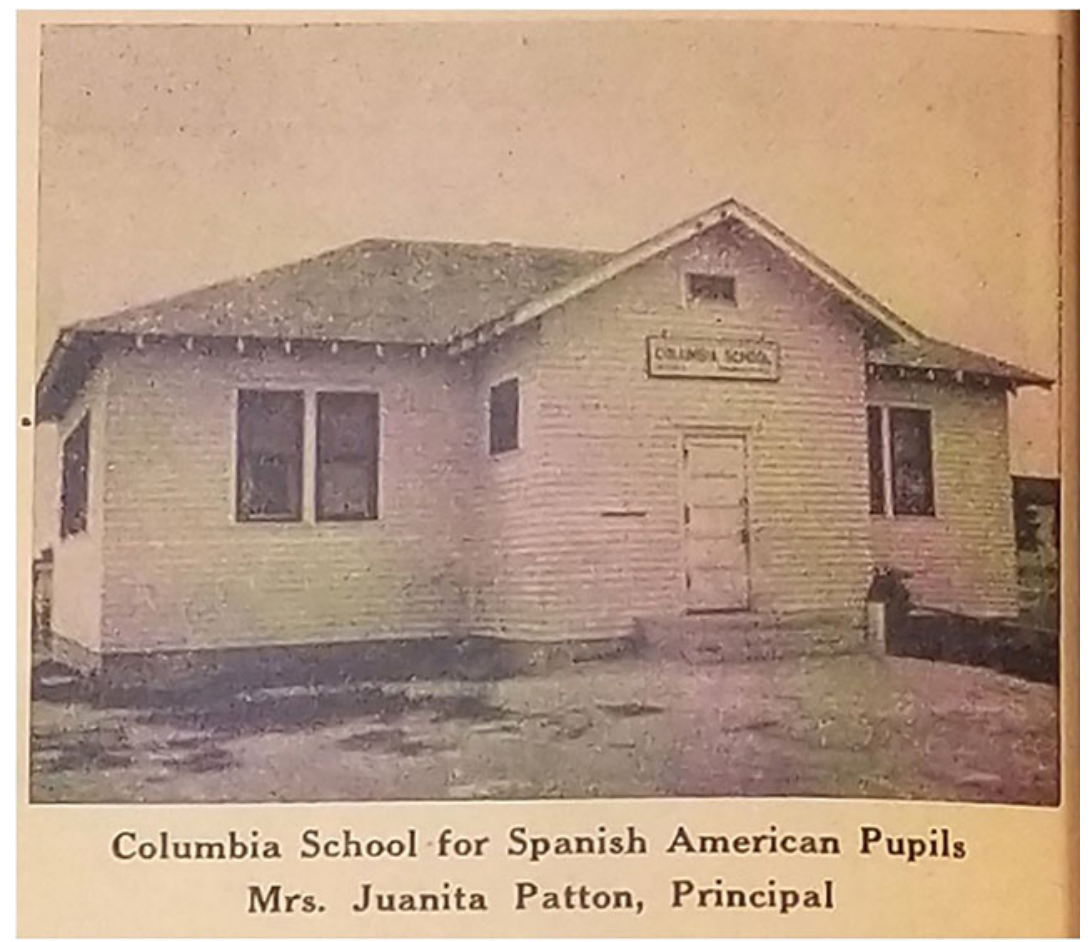

Figure 3. The Mexican School pictured in Torrington newspaper. Source: Torrington Telegram (WY), September 2, 1943, 4.

boycott the entire Torrington school system unless they were allowed to attend the city classrooms with the White children. Responding to the parents' protest, the superintendent, A. H. Dixon, allowed German Russians to reenter the city schools rather than force them to return to the South Torrington School. Consequently, by 1930, the school that was intended to serve all beet children became a "Mexican school." ${ }^{\prime 0}$ The incident in Torrington was an omen for the entire state as the Depression worsened, and Whites and German Russians looked to public schools to clarify and define their racial standing in the state.

Coronado, Aug. 5, 1973, Spanish Speaking Peoples in Utah-Oral Histories, item 137, box 5, Marriott Library, University of Utah, Salt Lake City, Utah; Sheriff Lee, Templeton, Brighton, Colorado, field notes, folder 25, carton 11, PSTP; “Mexican Boys Attacked in Brighton, Colorado," Aug. 1925, file: 311.1213, record group 59, Secretary of State Records, National Archives, College Park, Maryland; and R. W. Roskelley, interview by Stuart Marshall Jamieson, Sept. 22, 1940, folder 12, carton 1, Stuart Marshall Jamieson Collection, Colorado Interviews, Bancroft Library, UC Berkeley, Berkeley, California (hereafter cited SMJC).

${ }^{60}$ For a short history of the Mexican school in Torrington, see Juanita Patton to Grace Raymond Hebard, Jan. 18, 1930, folder 1, box 3, GRHP; A. H. Dixon, interview notes, April 28, 1931, folder 2, box 3, GRHP; Juanita Patton, interview by Stuart Marshall Jamieson, Sept. 22, 1940, folder 12, carton 1, SMJC. 
The Mexican Race and Child in Wyoming on the Eve of the New Deal, 1930-1933

The 1930s can be considered the nadir of race relations for Mexicans in the United States during the twentieth century. ${ }^{61}$ During this decade, the US Census Bureau created, for the first and only time, a racial category for "Mexicans" that set them apart from White Americans. ${ }^{62}$ The 1930s also saw an unprecedented deportation program that targeted Mexicans. This was an issue for Mexicans in sugar beet communities, where many sugar companies and local charity organizations coordinated repatriation to move Mexicans out of depressed areas. ${ }^{63}$ Deportation drives disproportionately focused on Mexicans-regardless of citizenship_-because they were racialized and were seen as "welfare dependent." ${ }^{\prime 4}$ Repatriation of Mexicans became so widespread that Mexican communities feared accepting or applying for relief. ${ }^{65}$ The repatriation program eventually deported approximately five hundred thousand Mexicans regardless of citizenship. ${ }^{66}$ As early as 1932, Wyoming newspapers acknowledged the massive repatriation of Mexicans. ${ }^{67}$ Wyoming alone saw almost two-thirds of the local foreign-born Mexican population depart by $1940 .^{68}$ However, Wyoming still had the largest percentage of Mexicans of all Mountain States outside of the Southwest. ${ }^{69}$

\footnotetext{
${ }^{61}$ In 1930 the US Senate voted to restrict immigration from Mexico. "News Bits about Our City, Our Country, and Elsewhere," Cheyenne (WY) Citizen, May 18, 1930, 2. For more on the impact of the Depression on the Mexican community in the US, see Fernando Saúl Alanís Enciso, They Should Stay There: The Story of Mexican Migration and Repatriation during the Great Depression (Chapel Hill: University of North Carolina Press, 2017); Franciso E. Balderrama and Raymond Rodríguez, Decade of Betrayal: Mexican Repatriation in the 1930s (Albuquerque: University of New Mexico Press, 2006); Donato, Mexicans and Hispanos, 49-89; Matt Garcia, A World of Its Own, 121-56; Camille Guérin-Gonzales, Mexican Workers and American Dreams: Immigration, Repatriation, and California Farm Labor, 1900-1939, 2nd ed. (New Brunswick, NJ: Rutgers University Press, 1996); Abraham Hoffman, Unwanted Mexican Americans in the Great Depression: Repatriation Pressures, 1929-1939 (Tucson: University of Arizona Press, 1974); Natalia Molina, Fit to be Citizens? Public Health and Race in Los Angeles, 1879-1939 (Berkeley: University of California Press, 2006), 116-78; and George J. Sánchez, Becoming Mexican American: Ethnicity Culture and Identity in Chicano Los Angeles, 19001945 (New York: Oxford University Press, 1993).

${ }^{62}$ For more on the controversy surrounding the categorization of the Mexican race, see Jennifer L. Hochschild and Brenna M. Powell, "Racial Reorganization and the United States Census 1850-1930: Mulattoes, Half-Breeds, Mixed Parentage, Hindoos, and the Mexican Race," Studies in American Political Development 22, no. 1 (Spring 2008), 59-96; Natalia Molina, “In a Race All Their Own': The Quest to Make Mexicans Ineligible for US Citizenship," Pacific Historical Review 79, no. 2 (May 2010), 167-201; and Patrick D. Lukens, A Quiet Victory for Latino Rights: FDR and the Controversy over "Whiteness" (Tucson: University of Arizona Press, 2012).

${ }^{63}$ Merleaux, Sugar and Civilization, 248; "Mexico Offers Aid to Its Subjects," Worland (WY) Grit, Jan. 6, 1938, 1 .

${ }^{64}$ Cybelle Fox, Three Worlds of Relief: Race, Immigration, and the American Welfare State, from the Progressive Era to the New Deal (Princeton, NJ: Princeton University Press, 2012), 129-32.

${ }^{65}$ Fox, Three Worlds of Relief, 134.

${ }^{66}$ Saúl Alanís Enciso, They Should Stay There, 16; Balderrama and Rodríguez, Decade of Betrayal, 26566; Adam Goodman, The Deportation Machine: America's Long History of Expelling Immigrants (Princeton: Princeton University Press, 2020), 46; Hoffman, Unwanted Mexican Americans in the Great Depression, 174-75.

${ }^{67}$ Paul Andrew Hassler, "Some Effects of the Great Depression on the State of Wyoming, 1929-1934" (master's thesis, University of Wyoming, 1957), 68.

${ }^{68}$ Lawrence Cardoso, "Mexican Immigration to Wyoming," box 9, folder 6, LCP.

${ }^{69}$ Cardoso, "Mexican Immigration to Wyoming."
} 
In Wyoming, the status of the Mexican child and laborer became increasingly salient as the Depression spread. On February 18, 1931, Governor Frank C. Emerson died, and by the end of the year the Child Labor and Welfare Committee had lost Hebard as its chair. ${ }^{70}$ The collapse of the committee coincided with the increasingly racist tone of many committee members and frustration on the part of many educational leaders regarding how to solve the state's Mexican beet children problem. In its final report on the sugar beet labor problem in Wyoming, the committee offered no viable recommendations on the best means to educate the children of the sugar beet fields. ${ }^{71}$ Beatrice McLeod, Wyoming state director of special education, in one of her last correspondences with Hebard on the Mexican schooling issues, lamented what seemed to be intractable issues and suggested that "further investigation is necessary to determine the educational needs of these children."72 Though the committee came to no definitive conclusions, its members began providing a racial explanation for the issues rather than explaining them in terms of immigrant or labor class status. The end of Emerson's Child Welfare Committee was a devastating blow to the fate of Mexican American children in the state. As observed in the committee's campaign, school and state officials were central in combating calls for racial segregation in Wyoming's public schools. With the committee gone, the educational fate of Mexican children was now left in the hands of communities that held anti-Mexican sentiment.

Correspondence from Thomas Mahony, head of Colorado's Mexican Welfare Committee, to Hebard is a case in point. ${ }^{73}$ Though Colorado sugar beet factories employed German Russians and native White Americans along with Mexicans, he described how Mexicans, in particular, were becoming targets as the economic situation in the state deteriorated. In his last correspondence with Hebard, he predicted Mexican sugar beet workers were in for a "terrible winter." 74 In Colorado, the Great Depression exasperated the anti-Mexican sentiment in sugar beet districts already present in the 1920 s. $^{75}$ However, Mahony observed an intensification of existing anti-Mexican sentiment in the 1930s, anticipating a larger shift in the relationship between the sugar beet industry and Mexican laborers:

\footnotetext{
${ }^{70}$ Amy Abbot to Hebard, March 4, 1930, folder 13, box 22, GRHP; Abbot to Hebard, March 10, 1931, folder 13, box 22, GRHP.

${ }^{71}$ Emerson's Child Welfare Committee, "Sectional Survey of the Educational Needs of Children Working in the Beet Fields of Goshen County" (unpublished manuscript, William R. Coe Library, University of Wyoming, 1930)

${ }^{72}$ Beatrice McLeod to Hebard, Dec. 19, 1930, folder 2, box 3, GRHP.

${ }^{73}$ For more on Thomas F. Mahony, see Donato, Mexicans and Hispanos, 13-29.

${ }^{74}$ Thomas F. Mahony to Hebard, July 24, 1930, Thomas F. Mahony: Manuscripts (CMAH) 1/10, Thomas F. Mahony Papers, University of Notre Dame Archives, Notre Dame, Indiana.

${ }^{75}$ For more on the anti-Mexican sentiment in Colorado during this period, see Tom I. Romero II, "Observations on History, Law, and the Rise of the New Jim Crow in State-Level Immigration Law and Policy for Latinos," American Quarterly 66, no. 1 (March 2014), 153-60; Tom I. Romero II., “A War to Keep Alien Labor Out of Colorado: The 'Mexican Menace' and the Historical Origins of Local and State Anti-immigration Initiatives," in Strange Neighbors: The Role of States in Immigration Policy, ed. Carissa Byrne Hessick and Gabriel J. Chin (New York: New York University Press, 2014), 63-96; and Monica W. Varsanyi, "Hispanic Racialization, Citizenship, and the Colorado Border Blockade of 1936," Journal of American Ethnic History 40, no. 1 (Fall 2020), 5-39.
} 
The company and others [sic] seem to be adopting a rather "hard-boiled" attitude towards them. I am receiving many reports of laborers not receiving their pay for the spring work. In a good many instances in addition to this, they are being driven off from ranches. A good many seem to have the idea that because of general unemployment throughout the country they can be rehired for fall work at a price less than the price specified in contract. ${ }^{76}$

The "hard-boiled attitude" Mahony described was not isolated to Colorado but extended to Wyoming. By the end of 1930, the tone in Wyoming began to change as both Hebard and educators throughout Wyoming began to describe the education of Mexican sugar beet students in racial and cultural terms, minimizing the discussion of beet children in general. Nothing displayed the drastic racialization more than one of Hebard's last correspondences regarding the beet children issue with fellow Child Welfare Committee member and future president of the state's Board of Education, J. J. Early:

It looks as if I wore [sic] emergency, temporarily perhaps, in making the preparation for six or seven weeks of special instruction for these children, who even though Mexican and dark skinned are human beings. . . . Not for publication, I would like to say I believe that Wyoming would be economically, socially, and educationally better off today if we had no Mexican laborers within our boundary. There would be a period, of course, of semi-adjustment that might be depressing, but ultimately there would be a standard of living and social equilibrium, which we do not possess now in some localities where there are numerous Mexicans. ${ }^{77}$

The anti-Mexican sentiment and attention to racial characteristics-skin colorwas a stark contrast to Hebard's discussion of Mexicans earlier in the educational campaign. The attention to skin - a biological trait-demonstrates that Hebard and her colleagues were transitioning to a racial difference rationale to explain the condition of the Mexican child in Wyoming schools ${ }^{78}$ Initially, the discussion of educating Mexican beet children centered on their eventual inclusion in the citizenry of Wyoming. ${ }^{79}$ Hebard's faith in that plan collapsed by the end of 1930 as the Great Depression worsened. In its place was a new faith in the racial segregation of Mexican children to solve a schooling problem that was increasingly viewed as a social problem in Wyoming. Before the New Deal, many Wyoming communities began to look for ways to segregate Mexican children just as economic constraints prevented them from doing so.

This change was reflected in areas such as the Torrington School District, where Mexican children continually found themselves shut out of the normal public school

\footnotetext{
${ }^{76}$ Thomas F. Mahony to Hebard, July 24, 1930, folder 2, box 3, GRHP.

${ }^{77}$ Hebard to J. J. Early, Dec. 25, 1930, folder 2, box 3, GRHP.

${ }^{78} \mathrm{Central}$ to racial difference was developing an aesthetic to race, such as seeing and naming skin color differences. See Mark Smith, How Race Is Made: Slavery, Segregation, and the Senses (Chapel Hill: University of North Carolina Press, 2006).

${ }^{79}$ Hebard to Senator Kendrick, Jan. 14, 1930, folder 1, box 3, GRHP.
} 
system, associated with poverty, and discussed in racialized terms. Juanita Patton, who was now teaching exclusively Mexican children by 1931, discussed the problems of teaching at a segregated school. Patton identified social discrimination as the source of isolation of Mexican children, stating, "A few came to the regular grade school in Torrington, but the White children fought them and called them dirty Mexicans, and the ones that came were not happy." 80 She also noted that Mexicans were cut out not only from the school system but from the welfare system in the community; many Mexican children did not attend school because of lack of clothing, shoes, and poor hygiene. In response, school officials had to create a "sort of Red Cross" to assist the Mexican students. ${ }^{81}$ However, Patton's concern for the welfare of Mexican children was not based on a belief in the eventual inclusion of Mexicans into Wyoming society but rather was the product of racial paternalism. ${ }^{82}$ She clearly marked Mexican and White children as opposites, and never discussed Mexicans and German Russians as the same student population, which was not the case before segregation. For instance, when writing to Amy Abbot of the Child Welfare Committee to describe the experience of Mexican students in the South Torrington School, Patton described Mexicans as racially and nationally different than Whites, stating, "Can you put yourself in their place, a lone white child in Mexico?" ${ }^{33}$ Once allowed into White schools, German Russian children ceased to be a named "educational problem," even though many still worked in the sugar beet fields. ${ }^{84}$

Patton was both a problematic advocate and teacher of Mexican children. Although acknowledging the discrimination faced by Mexicans in Wyoming and noting that Whites commonly referred to Mexicans in the community as just "dirty Mexicans," many times she also described the Mexican population as "child like," prone to drunkenness, engaged in wife beating, and unable to manage their finances, effectively making them complicit in their community standing. ${ }^{85}$ More importantly, she never questioned the segregation that emerged in her school, even though she noted that her school's racial segregation emerged out of racial negotiations between German Russian parents and White school officials. Patton was not alone in this analysis-A. H. Dixon, the school superintendent in Torrington, shared this view. In a telling interview of Dixon in 1931, he explained that anti-Mexican sentiment from the German Russian parents was a critical factor in racial segregation in the

\footnotetext{
${ }^{80}$ Patton to Abbot, Jan. 8, 1931, folder 2, box 3, GRHP.

${ }^{81}$ Mrs. Juanita Patton to Stuart Marshall Jamieson, Sept. 22, 1940, Mexican schoolteacher to Stuart Marshall Jamieson, folder 12, carton 1, Colorado Interviews, SMJC.

${ }^{82}$ Patton's racial paternalism toward Mexican children mirrored the relationship between White women and educators toward Indigenous children in the US West. See Margaret D. Jacobs, White Mother to a Dark Race: Settler Colonialism, Maternalism, and the Removal of Indigenous Children in the American West and Australia, 1880-1940 (Lincoln: University of Nebraska Press, 2009).

${ }^{83}$ Patton to Abbot, Jan. 9, 1931, folder 2, box 3, GRHP.

${ }^{84}$ As late as 1946, researchers noted that Mexican children were not the only ones working in the sugar beet fields yet were the only ones targeted for segregation. See T. Joe Sandoval, "A Study of Some Aspects of the Spanish-Speaking Population in Selected Communities in Wyoming" (master's thesis, University of Wyoming, 1946), 48.

${ }^{85}$ Patton to Jamieson, Sept. 11, 1940, folder 12 carton 1, SMJC.
} 
Torrington schools, particularly the school that German Russian parents had boycotted because their children were placed exclusively with Mexicans. ${ }^{86}$

The German Russian experience in Torrington and the rest of Wyoming is a reminder of the central role of schools in creating race. The final decision on segregation came down to Superintendent Dixon, who allowed German Russians to attend any school of their choice with White children, showcasing the power of school authorities to define race. Once the South Torrington School became segregated, Dixon fully embraced a racial view of education. For instance, when Dixon was interviewed in 1931 by a University of Wyoming student about the school, he observed, "The beautiful part of our system here in Torrington is that the school tries to let the Mexican put himself into his environment and not mold the environment to the Mex $[$ sic $] . "{ }^{\prime 87}$ As the interview proceeded, Dixon was more specific about the "Mexican environment," stating:

The Mexicans in this Colony like to be called the Spaniard. They have the clear eye, high forehead, smooth features, etc., but most of them are the offspring from the Indians and are not as high class as the Spanish of this type. However, it should be remembered that these Mexicans are the lowest of the low working classes who live in Mexico. ${ }^{88}$

His view of the German Russian element, especially students, was a striking contrast: "The Russian-Germans are quite regular in school and are in the main trustworthy as well as conscientious about their work." ${ }^{89}$ Dixon failed to reconcile or explain the placement of German Russian children in the same school with Mexicans in the first place, considering the school was best suited for the Mexican child. ${ }^{90}$ Additionally, the attention to racial attributes and "color" was a marked contrast from his discussion of Mexicans as simply a "foreign element," as shown in his correspondences with the Wyoming Committee for Child Welfare in 1929. ${ }^{91}$ For Dixon, the Mexican was a racial other distinct from Whites, including the previously racially ambiguous German Russians, and the South Torrington School, now the "Mexican School," operationalized and fixed this racial view. ${ }^{92}$

\section{Creating the Mexican Race: Segregated Mexican Rooms and Schools in New Deal Wyoming, 1934-1941}

The worsening conditions of the sugar beet industry, dire need for relief in sugar beet communities, and the avalanche of protests by Mexican and Mexican American sugar

\footnotetext{
${ }^{86}$ Dixon, interview notes, April 28, 1931, GRHP.

${ }^{87}$ Dixon, interview, GRHP.

${ }^{88}$ Dixon, interview, GRHP.

${ }^{89}$ Dixon, interview, GRHP.

${ }^{90}$ This also was a clear deviation from the original intent of the Wyoming Child Welfare Committee to solve the Mexican child absenteeism problem. See Grace Abbott, Eighteenth Annual Report of the Chief of the Children's Bureau to the Secretary of Labor (Washington, DC: Government Printing Office, 1930), 33.

${ }^{91}$ A. H. Dixon to Hebard, Nov. 29, 1929, folder 1, box 3, GRHP; and "One Hundred Per Cent American Projects," Powell (WY) Tribune, May 10, 1923, 2.

${ }^{92}$ Kevin Fox Gotham, "Racialization and the State: The Housing Act of 1934 and the Creation of the Federal Housing Administration," Sociological Perspectives 43, no. 2 (June 2000), 294-95.
} 
beet workers forced federal intervention. The passage of the 1934 Sugar Act included a minimum wage scale for beet workers and a child labor clause. ${ }^{93}$ The child labor provision caused little protest by sugar beet officials and politicians, who saw their biggest concern as the increasing unionization and radicalization of Mexican workers. ${ }^{94}$ Many viewed the curtailing of Mexican child labor in the sugar beet fields as a pathway toward higher wages for Mexican heads of families, with many arguing said action would lead to "freedom from premature toil in the beet fields and improved opportunities of school attendance for the children, together with higher wages, increased work opportunities, and improved living conditions for their families." 95 However, it would be the child labor restrictions implemented in 1935 that would be most impactful. For Wyoming, the 1934 Sugar Act-renewed in 1937brought the Mexican child and schooling into a racialized New Deal.

With the passage of the federal act, sugar beet growers could not apply for federal loans or assistance if they utilized child labor under fourteen years old. ${ }^{96}$ A survey from the National Child Labor Committee found widespread compliance with the clause in the sugar beet industry, reporting, "Statements by land owners, renters, and laborers indicated that the child labor provisions of the 1935 contracts had been carried out both in the letter and spirit of the law." 97 In communities like Lovell, Torrington, and Worland, this had an immediate impact as local newspapers called on growers and the sugar beet industry to comply with the Sugar Act. ${ }^{98}$ According to a 1935 survey by the US Department of Labor's Children's Bureau, the usage of child labor ages six through twelve dropped from 22.5 percent to 7.35 percent in northern Wyoming. ${ }^{99}$ Combined with the issue of relief, the Sugar Act curtailed the prevalence of beet children and increased the presence of Mexican children in the Wyoming schools, an unwelcome addition in many White communities.

As part of the Sugar Act, the Children's Bureau sent a number of agents to sugar beet-producing states to assure that anti-child labor provisions were being

\footnotetext{
${ }^{93}$ The Sugar Act of 1934 was also known as the Jones-Costigan Amendment to the 1933 Agricultural Adjustment Act (AAA) that designated sugar beets a basic commodity in an attempt to salvage domestic sugar production in the US. See also, "Conclude Hearings on Sugar Question," Lovell Chronicle (WY), Oct. 4, 1934, 3; and "Sugar Beet Labor Provisions Signed," American Child 16, no. 9 (Dec. 1934), 2.

${ }^{94}$ Merleaux, Sugar and Civilization, 255-56.

${ }^{95}$ Elizabeth S. Johnson, Welfare of Families of Sugar-Beet Laborers: A Study of Child Labor and Its Relation to Family, Work, Income, and Living Conditions in 1935 (Washington, DC: Government Printing Press, 1939), 83.

${ }^{96}$ Adela J. Ballard, “The Migrant Mexican,” Nov. 14, 1933, folder 11, box 15, Home Mission Council Records, Presbyterian Historical Society, Philadelphia, Pennsylvania.

${ }^{97}$ Charles E. Gibbons, “The Beet Fields Revisited," American Child 18, no. 6 (Sept. 1936), 1.

98“Child Labor Beet Contract Provision Cited," Worland Grit (WY), June 27, 1935, 3; "Child Labor Provision Cited in Beet Contract," Lovell Chronicle (WY), July 4, 1935, 1; and "Child Labor Rules Cited," Torrington Telegram (WY), July 4, 1935, 3. The interplay between agricultural labor demands, increased federal oversight, and race in schools mirrored similar developments in other states, such as Texas. See Carlos Kevin Blanton, "Race, Labor, and the Limits of Progressive Reform: A Preliminary Analysis of the Enforcement of Compulsory Attendance in South Texas during the 1920s," Journal of South Texas 13, no. 2 (Fall 2000), 207-19.

${ }^{99}$ Johnson, Welfare of Families, 86; William T. Ham, "Sugar Beet Labor under the AAA," Journal of Farm Economics 19, no. 2 (May 1937), 645.
} 
observed. $^{100}$ In northern Wyoming-Big Horn, Park, and Washakie Countiesagents found educational neglect of Mexican beet children. In one glaring example, one school district had actively discouraged Mexican children from attending school. The agents discovered that in many communities, the restriction of child labor did not translate into increased enforcement of the state's compulsory attendance laws. ${ }^{101}$ In one case, agents found that in an unnamed Wyoming town, school officials "at their own discretion, refused to admit children who did not enroll in the first 15 days of the school term." 102 This policy chiefly affected Mexican children, since many were from migrant families. One Mexican family that permanently resided in the town had to enroll their children almost two years late, with one child entering the first grade at nine years old. ${ }^{103}$ In another community, children from a local Mexican colony were not offered school bus services. In the winter, many Mexican children from the colony had to run as fast as possible to school in an effort to keep from "being thoroughly chilled." ${ }^{104}$ The 1935 study by the Children's Bureau discovered that race displaced class in public schools. The most common distinction made in the application of school-attendance standards was that of "Whites" and "Mexicans." 105

In the wake of the New Deal and the passage of the 1934 Sugar Act, Wyoming witnessed the creation of segregated Mexican rooms and entire schools in sugar beet communities with a noticeable Mexican student population. Although communities adopted different types of segregation, ranging from a segregated grade room to an entire school, segregation was expanded in schools across the state. The explanation of the need for segregation took on an overtly racist tone in some instances, a tone that was at odds with how Mexican students had been described in the past, even as recently as 1929. In Torrington, what was once the South Torrington School for German Russian and Mexican children by 1932 was exclusively for Mexican students and recorded as the "Mexican School" in superintendent reports and newspaper reports. ${ }^{106}$ In Torrington, it was public policy that no children from the Mexican Colony or Mexican District were allowed in the city schools. ${ }^{107}$ In Lovell, a segregated, ungraded classroom named the "Mexican Room" in an official ledger was reserved only for "maladjusted" Mexican children-all Mexican children were considered maladjusted. These children, a paper explained, "are backward because they are unable to speak the English language, and the White children do not accept them into the social life of the school. This condition gives rise to an

\footnotetext{
100“Employers Pay Back Wages-Gained by Efforts of AAA Representatives," Wyoming Labor Journal, Oct. 4, 1935.

${ }^{101}$ Johnson, Welfare of Families, 47.

${ }^{102}$ Johnson, Welfare of Families, 48.

${ }^{103}$ Johnson, Welfare of Families, 48.

${ }^{104}$ Johnson, Welfare of Families, 73.

${ }^{105}$ Johnson, Welfare of Families, 47.

${ }^{106}$ Goshen County Superintendent of School Reports, Annual Reports 1932-1933, Goshen County, Wyoming Records, Wyoming State Archives, Cheyenne, Wyoming (hereafter cited as WSA).

107"News from the Public Schools of Torrington," Torrington Telegram (WY), Sept. 14, 1933, 5; and "Mexican School News," Torrington Telegram, Supplement to the Torrington Telegram, Dec. 5, 1935, 3. For a larger discussion of the school, see Dixon, interview notes, April 28, 1931, folder 2, box 3, GRHP.
} 
educational problem." ${ }^{108}$ In neighboring Powell, officials debated the creation of an entirely separate school based on the same logic, ultimately opting to create a segregated school for the local Mexican children. ${ }^{109}$ Only after population pressures demanded a new school for White students did the Powell school board abandon its plans for a Mexican school, but it continued to maintain a segregated Mexican classroom. ${ }^{110}$ In Basin, the school board actively recruited a teacher for just the Mexican children in the community. ${ }^{111}$ Deaver-a small town of only a hundred with a minor Mexican presence-developed its own segregated Mexican room, despite having only one school for all grades. ${ }^{112}$

Mexican children experienced discrimination even in schools outside the sugar beet districts. In one account from the mining community of Sunrise, a Mexican student recalled that "speaking Spanish was strictly forbidden, and Mexican students were beaten if they strayed into their home language." "In Worland, an entirely new school was built exclusively for Mexican children with New Deal funds. The school was interchangeably called the Mexican or Spanish School.

The segregated school is Worland is a particularly compelling example, since the city created a separate school for Mexican children, not just a separate classroom. Worland serves as a case study that racial understandings-not demographic, economic, or labor pressures-created and accelerated segregation in the Wyoming schools. Unlike most communities, Worland had successfully weathered both the Depression of the 1920s and 1930s. ${ }^{114}$ For Washakie County (where Worland was located), a small county with a diverse farming economy and a sugar beet factory, the 1930s was described as the "construction decade." ${ }^{115}$ In an early survey of relief conditions in Wyoming, Washakie County was found to rank last in percentage of population on relief in the state. Of this segment, only 2.1 percent were Mexican,

\footnotetext{
${ }^{108}$ J. A. Caudill, “A Survey of Certain Phases of the Public Schools of Lovell, Wyoming” (master's thesis, University of Wyoming, 1938), 5, 46-47; and Big Horn County Superintendent of School Reports, Annual Report of the Superintendent 1936-1937, Wyoming Records, WSA.

109"Problem Faces School Board of Providing Room for Grade School," Powell Tribune (WY), March 18, 1937, 1; "Ask Bids for Construction of New School Building in Powell," Powell Tribune, Sept. 30, 1937, 1; and "Construction Delayed Proposed Mexican School Building," Powell Tribune, Nov. 11, 1937, 1.

110"New Building Plans of School Board to Avail Themselves of Federal Assistance," Powell Tribune, July 28, 1938, 1. Also see Park County Superintendent of School Reports, Annual Report of the Superintendent 1933-1934, Wyoming Records, WSA.

111 "Increase Staff," Billings Gazette (MT), March 16, 1934, 15.

${ }^{112}$ The room was recorded as the "Mexican Room" in the official ledger in superintendent reports. See Big Horn County Superintendent of School Reports, Annual Report of the Superintendent 1933-1934, Wyoming Records, WSA.

${ }^{113}$ For an account in the mining districts of Wyoming, see Ronald Mize and Alicia Swords, Consuming Mexico Labor: From the Bracero Program to NAFTA (Toronto: University of Toronto Press, 2010), xvi; Timothy Dean Draper, “A Little Kingdom of Mixed Nationalities': Race, Ethnicity, and Class in a Western Urban Community-Rock Springs, Wyoming, 1869-1929” (PhD diss., Northern Illinois University, 2007), 233-34.

114"Worland Known over the Nation," Worland Grit, Jan. 6, 1928, 2.

${ }^{115}$ Ray Pendergraft, Washakie: A Wyoming County History (Powell, WY: Saddlebag Books, 1985), 17880; and "New Worland School Opens Doors Monday," Billings Gazette, Nov. 29, 1936, 12.
} 
but they made up almost 10 percent of the entire county. ${ }^{116}$ Almost 98 percent of all relief families in Washakie County were White. ${ }^{117}$ Unemployment was steady throughout the county, reaching its peak in the winter months, but never exceeding a total of four hundred people unemployed, thus consistently putting the county lowest among the beet-producing counties. ${ }^{118}$ Yet it was in Washakie County where racial segregation in public schools reached its apogee in the state. Such a development is even more interesting considering that in the early 1930s the education of the Mexican child was temporarily in the background of public community concerns.

From 1930 to 1933, there was little to no discussion in the local newspapers or the school board minutes of segregating Mexican students in Worland. In fact, there was no discussion of the beet child problem publicly in the community. ${ }^{119}$ Although there was some discussion about deportations of Mexicans, little was said on the status of educating Mexicans during this period. ${ }^{120}$ For instance, a report from the Mexican consul in Denver, Colorado, found that 14,068 Mexicans were deported back to Mexico from Colorado and Wyoming by 1933, including Worland. ${ }^{121}$ Still, the schooling of the local Mexican American and Mexican children was seemingly a nonissue. Interestingly, in early 1934, the school board minutes indicated there was some protest on the division of the elementary grades into three tracks, because students in the " $C$ " track-the lowest one-felt marginalized. ${ }^{122}$ At that time, all students, regardless of race, were placed in educational divisions based on ability.

This inattention changed during a special roundtable convened at the local Parent Teachers Association meeting in the spring of 1934. The major topic of discussion was constructing a separate school for the "foreign" or "Mexican element" in the community. ${ }^{123}$ German Russians, unlike Mexicans, would attend the "regular" White schools. The special roundtable was headed by elementary school superintendent Frank Watson and included G. C. Muirhead of the governor-appointed and New Deal-funded Wyoming State Planning Commission. ${ }^{124}$ The meeting ended with a yes vote in favor of constructing the segregated school and securing aid from the local sugar factory, the Wyoming Emergency Relief Administration, and other government relief agencies. Muirhead was the one who suggested the school district should apply

\footnotetext{
${ }^{116}$ For data see Eri Hulbert, Report of the Study of the Public Welfare Services of the State of Wyoming (Cheyenne: Wyoming Charities and Reform Board, 1934), 108; US Census Bureau, Fifteenth Census of the United States: 1930: Population, Volume 3, Part 2 (Washington, DC: Government Printing Office, 1931), 1387.

${ }^{117}$ Hulbert, Report of the Study, 108.

118“Unemployment in the Big Horn Basin (Wyoming and Montana)," in Charles C. Colby and S. R. DeBoer, "Big Horn Basin Wyoming and Montana" (unpublished report, Denver, June 1941), folder FF36, box 7, S. R. DeBoer Papers, Denver Public Library, Denver, Colorado.

${ }^{119}$ A passing reference was made to "beet families" in some newspaper accounts of schools. See "County Schools Open in Record Attendance," Worland Grit, Sept. 8, 1932, 1.

${ }^{120}$ There is no mention of the Mexican or foreign student population in any of the Board of Trustee Minutes for the Worland School District from 1930 to 1933. See Washakie Co. School Board of Trustee Minutes, 1930-33, WCSR.

121 "Beet Field Work Aids Employment," Worland Grit, Aug. 10, 1933, 3.

${ }^{122}$ Minutes, June 18, 1934, Board of Trustees, Annual Meeting of School District No. Six, WCSR.

123“P.T.A. Meeting," Worland Grit, March 29, 1934, 4.

124"P.T.A. Meeting."
} 
for relief funds to fund the construction of the segregated school. ${ }^{125}$ The meeting demonstrated the continued collaboration between school officials and the sugar beet industry. For the Mexican community, the continued collusion between White factory owners, state representatives, and White school officials regarding school policy left Mexican children in Wyoming vulnerable to shifting attitudes toward race. After the meeting, the matter of segregation was then presented to the local school board for approval.

During the Worland School Board of Trustees meeting in 1934, Frank Watson once again brought up the matter of a segregated school. "Mr. Watson brought up the matter of a separate school building for foreign children near the foreign settlement," read the meeting's minutes. "It was thought the matter was worth looking into to see what might be accomplished." "26 This suggestion for a segregated school symbolized the rise of race in marking citizenship in Worland. This was particularly true of Watson, considering that, as recently as 1929, he and Worland school officials had opposed segregating Mexican children. The calls for segregating Mexican children grew louder as Worland school officials wrote letters to the chairman of the Wyoming State Planning Board and the Holly Sugar Company factory manager, inquiring about possible assistance in building a separate school for the "non American" students. One letter read, "The Board feels the segregation of this class of pupils in a separate building will be for the good of both classes of students." The secretary of the school board added, "Knowing the Holly Sugar Corporation has co-operated in other places along this line, the Board asked that the matter be taken up with you and solicit such co-operation here. We have in mind that possibly some Government Relief Agency would co-operate also." ${ }^{\prime 27}$ Worland officials probably thought their chances were quite good given that the Holly Sugar Company had given assistance to the schooling of Mexican children in other towns. ${ }^{128}$ The same school officials also asked the Wyoming Commissioner of Education and Government Relief Agencies for some additional assistance. ${ }^{129}$ The school board opted to apply for federal New Deal funds to construct the new school.

In applying for federal and state aid for the new school, Worland school and city officials deviated from the reasons historically cited for segregating Mexican American children, including their perceived lack of English proficiency, their child labor status, or both, instead opting for a purely racial segregation rationale. ${ }^{130}$ For instance, in their Public Works Administration (PWA) and Works Progress

125“P.T.A. Meeting."

${ }^{126}$ Minutes, Feb. 10, 1934, Board of Trustees, Directors Meeting, School District No. 6, WCSR.

${ }^{127}$ Minutes, Washakie Co. School Board of Trustees, School District No. 6, to L. E. Laird, Superintendent, Holly Sugar Corporation, Worland, Wyoming, July 9, 1934, WCSR; and First Biennial Report State Planning Board 1935-1937 (Cheyenne, WY: State Printing Office, 1937), 2.

${ }^{128}$ Donald Alexander McNaughton, "A Social Study of Mexican and Spanish-American Wage-Earners in Delta, Colorado” (master's thesis, University of Colorado, 1942), 27; C-6 Welch, Principal of School, Swink, Colorado, interview notes, folder 12, carton 12, PSTP, 44-46; and Donato, Mexicans and Hispanos, 70, 72.

${ }^{129}$ Minutes, Nov. 9, 1934, Washakie County School Board of Trustees, School District No. 6, Worland, Wyoming, WCSR. By 1935, school board minutes had mentioned the Mexican school. See Minutes, March 15, 1935, Board of Trustees Directors Meeting, School District No. 6, WSCR.

${ }^{130}$ For a summary of the reasons cited for segregating Mexican American children, see Guadalupe San Miguel Jr. and Rubén Donato, "Latino Education in the Twentieth-Century America: A Brief History," in 
Administration (WPA) funding applications under the "Justification" heading, Worland officials wrote, "That the Mexican children may be segregated from the white children, the project is socially desirable." ${ }^{\prime 31}$ Despite the explicitly racist premise given, Worland's PWA and WPA applications were approved. ${ }^{132}$

In follow-up school board meetings, the "Mexican School" was recorded in official school board minutes. ${ }^{133}$ The naming of the "Mexican School" is significant because it negates a pedagogical basis for segregating Mexican American children and documents a racial reasoning. In a 1974 desegregation case in Oxnard, California, similar language in school board minutes from the 1930s served as evidence in a ruling against the school district. The court ruled that a term such as "Mexican school," demonstrating segregation in Oxnard, was not voluntary or based on educational standards but racial in nature. ${ }^{134}$

Soon after Worland officials had received federal and state support, they moved quickly to construct the school, which opened in $1936 .{ }^{135}$ Worland represents one of the few cases of federal documentation confirming that New Deal funding was explicitly approved and used to segregate Mexican children in a place where segregation did not exist earlier. The school's construction also violated a Wyoming school law that forbade any distinction or discrimination in public schools "on account of sex, race, or color."136

On the eve of the opening of the segregated school, a front-page article in the newly established Wyoming News justified the new school to the general public as a racial project:

The new grade school in the Mexican Colony, which is being built for the children of the Spanish-speaking people to segregate them from the regular schools, is being rapidly completed. The school will be a model building. . . . It is the intention of the board, as soon as practical, to employ only the best grade

Handbook of Latinos and Education: Theory, Research, and Practice, ed. Enrique G. Murillo Jr. (New York: Routledge, 2010), 30.

${ }^{131}$ Wyoming WPA Project Files, reel 107, OP 65-83-272, document \#7396, National Archives and Records Administration, College Park, Maryland (hereafter cited as NARA). Historian Michael Cassity briefly mentions the WPA application for the school but does not discuss its construction or the PWA application that had much more information. See Michael Cassity, Building Up Wyoming: Depression-Era Federal Projects in Wyoming, 1929-1943 (Cheyenne: Wyoming State Historic Preservation Office, 2013), 154-55.

132“"P.W.A. Approves Grant for Mexican School Here," Worland Grit, Oct. 3, 1935, 1; and "Approve Grant for School for Mexicans Here," Wyoming News (Worland, WY), Sept. 28, 1935, 1.

${ }^{133}$ Minutes, March 16, 1935, Washakie County School Board of Trustees, Directors Meeting, School District No. 6, WSCR. The Mexican School was also named in official census maps. See 1950 Census Enumeration District Maps, Wyoming, Washakie County, Worland, enumeration district (ED) 22-6 to 10, digital image, https://catalog.archives.gov/id/75639495.

${ }^{134}$ For more discussion on this desegregation case, see Joe C. Ortega and Peter D. Roos, "Chicanos in the Schools: An Overview of the Problems and the Legal Remedies," Norte Dame Law Review 75, no. 51 (Oct. 1975), 79-81; García, Strategies of Segregation, 129-62; and Richard Valencia, Chicano Students and the Courts: The Mexican American Legal Struggle for Educational Equality (New York: New York University Press, 2008), 67-70.

135“School Started in New Spanish Bldg," Worland Grit, Dec. 3, 1936, 1.

${ }^{136}$ Wyoming's antidiscrimination law in schools was established in 1889. See Pauli Murray, ed., States' Laws on Race and Color (Athens: University of Georgia Press, 1950), 521. 
teachers of the Spanish race ... with the ever increasing attendance of more children in the regular schools here it has been impossible to accommodate them and it was decided by the educational board here that by segregating the children of the different race, it would work out more economically and more satisfactory to all concerned. As the Mexican labor is always in demand here in the valley, the children growing up will be developed into the highest class of citizens. ${ }^{137}$

The newspaper never mentioned any pedagogical justifications or that Hebard and Worland's school officials had regarded the segregation of the races in schools as detrimental to developing the "highest class of citizens" as recently as 1929. Additionally, the justification that all children of the "Spanish race" were necessarily segregated was never fully explained, given that Mexican children in the upper grades were allowed to attend the regular schools and were observed as "very good students." ${ }^{138}$ The attention to the increase in population was ironic considering the overall Mexican population in Wyoming was decreasing. ${ }^{139}$ Thus the response by the White community to schooling the Mexican child was based on a change in racial views and the presence of a more stable Mexican student population. As political scientist Benedict Anderson so aptly demonstrated, sometimes imagined communities are more powerful than real ones. ${ }^{140}$ In this case, the imagined view of the Mexican as a distinct and lesser race than Whites justified racial segregation.

In the winter of 1936, the school was completed, and over one hundred Mexican American children were bussed from their former integrated school to the new segregated Mexican School. ${ }^{141}$ The construction of the Mexican School in Worland in 1936 constituted a drastic policy change from the community that once considered Mexican children a "better class" than German Russians. Worland not only promoted its new Mexican School but openly embraced the new inferior status of the Mexican student. For instance, the major newspapers in the county, the Wyoming News, the Worland Grit, and the Northern Wyoming Daily News, ran a weekly column on "Worland Grade Schools" with a separate "Spanish School" section in a tone almost celebratory in regard to segregation. Also, the Wyoming News reported specifically on news from the Mexican colony in Worland, called "News at the Colony," celebrating the newly built settlement for the Mexican population, constructed at the same time as the school. ${ }^{142}$ Everything about the school was modern, a product of New Deal

\footnotetext{
137“Spanish School Is Nearing Completion," Wyoming News, Oct. 16, 1936, 1.

${ }^{138}$ Studebaker to Hebard, Nov. 13, 1929, folder 1, box 3, GRHP.

${ }^{139}$ According to Mexican consul records from Denver, Colorado, from 1929 to 1933, almost 14,068 Mexican citizens were returned to Mexico from Colorado and Wyoming. See "Beet Field Work Aids Employment," Worland Grit, Aug. 10, 1933, 3.

${ }^{140}$ Benedict Anderson, Imagined Communities: Reflections on the Origin and Spread of Nationalism, rev. ed. (New York: Verso, 2006), 6-7; and Robert Miles, Racism after "Race Relations" (New York: Routledge, 1993), 56-59.

141 "New Worland School Opens Doors Monday," Billings Gazette, Nov. 29, 1936, 12. See also Ray Pendergraft, Washakie: A Wyoming County History (Basin, WY: Saddlebag Books, 1985), 180; and Alberta Seaman, A History of Washakie County, As Written by Its People: A Washakie County Bicentennial Project (Worland, WY: Northern Wyoming Daily News, 1976), 10.

${ }^{142}$ For an example of this column, see "News at the Colony," Wyoming News, Jan. 5, 1936, 8. The Mexican Colony was also named in the official census of Worland. See 1940 US census, Washakie
} 
relief in action. The school, described as a "fine facility," was a modern brick school with four rooms and teachers for each of the four grades. ${ }^{143}$ As noted by Worland school officials and WPA reports, "only a few of the best" ever made it to the eighth grade and rarely did any go on to graduate high school. ${ }^{144}$ Thus, racial understanding of Mexican educational achievement was mapped onto the Mexican School, ensuring the underachievement of Mexican children. ${ }^{145}$

The facilities at the Worland Mexican School were in stark contrast to the description of most Mexican schools of the Southwest, characterized as vastly inferior to White schools and having "inadequate resources, poor equipment, and unfit building construction." ${ }^{146}$ Even studies of Worland from the post-World War II era described the Mexican School as a "fine facility." ${ }^{47}$ Scholars have debated the rationale of building a segregated school that was modern and, in some cases, more attractive than White schools. Historian Gilbert G. González in his study of Southern California found similar exceptions and argued that this was a deliberate strategy by White school boards. To González the schools were designed as an attempt to make segregated schools more readily acceptable to Mexican parents. ${ }^{148}$ However, educational scholar and Mexican American civil rights leader George I. Sánchez advanced a more insidious justification: it made segregation more permanent. ${ }^{149}$ Illuminating this view was Sánchez's comments regarding the debate over improving segregated Mexican schools versus pursuing full racial integration:

County, Wyoming, Worland town, population schedule, enumeration district (ED) 22-6, sheet 26A-26B (handwritten), digital image, https://catalog.archives.gov/id/139282710, citing NARA microfilm publication T627, roll 4577.

${ }^{143}$ Sandoval, "A Study of Some Aspects of the Spanish-Speaking Population," 47; and "Two Teachers in Grade School Resign,” Worland Grit, April 13, 1939, 1.

${ }^{144}$ Robert Smith, "Racial Elements [Washakie County]"; "Worland, Wyoming," WPA file \#1252, WPA Collection, Wyoming State Archives, Cheyenne, Wyoming (hereafter cited as WPAC). For similar language used toward Mexican children in Oxnard, California, see David G. García, Tara J. Yosso, and Frank P. Barajas, "A Few of the Brightest, Cleanest, Mexican Children': School Segregation as a Form of Mundane Racism in Oxnard, California, 1900-1940," Harvard Educational Review 82, no. 1 (April 2012)," 3, 11-12.

${ }^{145}$ These mirrored similar developments in the US West and elsewhere. For examples, see Rubén Donato and Jarrod Hanson, The Other American Dilemma: Schools, Mexicans, and the Nature of Jim Crow, 19121953 (Albany: State University of New York Press, 2021); García, Strategies of Segregation, 79-99; David G. García and Tara J. Yosso, "Strictly in the Capacity of Servant': The Interconnection between Residential and School Segregation in Oxnard, California, 1934-1954," History of Education Quarterly 53, no. 1 (Feb. 2013), 68; González, Chicano Education in the Era of Segregation, 188-89; Victoria-María MacDonald, ed., Latino Education in the United States: A Narrated History from 15132000 (New York: Palgrave Macmillan, 2004), 55-92; and Guadalupe San Miguel Jr., "Let Them All Take Heed": Mexican Americans and the Quest for Educational Equality in Texas, 1910-1981, 2nd ed. (College Station: Texas A\&M University Press, 2001).

${ }^{146}$ González, Chicano Education in the Era of Segregation, 22.

${ }^{147}$ Sandoval, "A Study of Some Aspects," 47.

${ }^{148}$ Gilbert G. González, Labor and Community: Mexican Citrus Worker Villages in a Southern California County, 1900-1950 (Chicago: University of Illinois Press, 1994), 104.

${ }^{149}$ For the most extensive treatment of George I. Sánchez's career, see Carlos Kevin Blanton, George I. Sánchez: The Long Fight for Mexican American Integration (New Haven, CT: Yale University Press, 2014). 
It is exceedingly easy, and therefore particularly dangerous, to want to make the segregated school more efficient and more attractive. Usually, this means that it becomes increasingly difficult to eliminate segregation since the segregated institutions has been made more attractive, more palatable, and sometimes has attained a peculiarly prized prestige. . . But as I have said in past addresses, the segregated school is a concentration camp-you may gold plate the fence posts and silver plate the bobbed [sic] wire and hang garlands of roses all the way around it, it is still a concentration camp!! ${ }^{150}$

In Worland, the Mexican School was the most modern and newest school in the community, yet no White children ever attended the school. Whereas the architecture and conditions differed from that of most Mexican schools of the era, the emphasis on an Americanization curriculum in a segregated space was the same. ${ }^{151}$ In the Mexican School all instruction was designed to solve an English-language proficiency problem and to teach Mexican children "how to be American," as alumna Estela Vasquez described. ${ }^{152}$ This was a clear departure from the pre-segregation era, when instruction was focused on remedial education with the final outcome of integration.

Wyoming education officials also made no distinction between the Mexican child and parent during this time. Mexican parents throughout the state were also targeted for Americanization education, illustrating the consolidation of a distinct "Mexican" racial category in Wyoming during the 1930s. ${ }^{153}$ WPA officials observed similar accounts focused on the education of Mexican adults throughout the state, such as in the sugar beet district in Platte County:

It was our privilege to attend at one time the meeting of a class in Platte County where one of our teachers was instructing a group of Mexican beet workers in the rudiments of the English language and business procedure... . This appealed greatly to those childlike people from below the border who under the sympathetic instruction given made rapid progress. ${ }^{154}$

Observers described similar classes throughout the state in which the Mexican community was vocal about its appreciation of these courses. ${ }^{155}$ Although Mexicans were not the only group recorded as taking "Americanization" courses, they were the center of such racial descriptors as "childlike" and the assumption

\footnotetext{
${ }^{150}$ As cited in Carlos Kevin Blanton, "A Legacy of Neglect: George I. Sánchez, Mexican American Education, and the Ideal of Integration, 1940-1970," Teachers College Record 114, no. 6 (June 2012), 9.

${ }^{151}$ González, Labor and Community, 204.

152“"Grade School Notes," Worland Grit, March 25, 1937, 2; and Estela Vasquez, interview by author, Wapato, Washington, Sept. 23, 2014.

${ }^{153}$ As noted by the Worland Grit, "No teaching at all is done in Spanish. If any other instruction other than speaking in English is needed, dramatization is used." See "Grade School Notes," Worland Grit, March 25, 1937, 2.

${ }^{154}$ E. E. Dagley, "Wyoming Narrative Report, Works Progress Administration, Jan. 21, 1937 to Feb. 20 , 1937," Wyoming March 37 file, box 60, RG 69, NARA, 15-16.

155“For Earmarked Emergency Adult Education," Wyoming Projects folder, box 33, RG 69, NARA; "Mexican Night School Is Closed," Worland Grit, March 11, 1937, 1.
} 
that all were foreign-born. Many teachers emphasized the skin color of Mexicans attending night school, with one account from Torrington stating, "There were twenty-three or four men, their dark faces bent over their primers, learning to read and others doing their sums." ${ }^{156}$ In Worland, adult education for Mexican beet workers was promoted as a relief activity, to assist but not change their status as a beet laborer. $^{157}$

The creation of the Mexican School in Worland not only reverberated through Wyoming but reflected a larger racial project in which Whites throughout the Mountain States were demanding racial segregation. As a researcher from the Children's Bureau noted about the entire Mountain States region, "The public schools in the locales where the Mexicans work ... are not anxious to receive them [Mexican children] and in many districts do not encourage them to enroll but almost discourage them." ${ }^{158}$ In Scottsbluff County, Nebraska, one woman observed that, "The prejudice against the Mexican is very great. In Nebraska they house separate schools for the race[s] because the 'white' people object to them [Mexicans] attending 'white schools." 159 An earlier 1924 study of the sugar beet industry in Scottsbluff by the National Committee on Child Labor found segregation to be rare: "Their [Mexican] children attend the public school and only in rare instances are separated from other children into classes or rooms by themselves." ${ }^{\prime 160}$ By the end of 1936 when the Worland Mexican School was open, there were instances of racial segregation of Mexican American and Mexican immigrant children in every Mountain State, effectively constituting separate Mexican and non-Mexican social worlds in relief, medical care, and schooling. ${ }^{161}$ This affirmed the expansion of racial segregation in public schools that was well in place in the Southwest in the 1920s but encompassed almost all of the US West by the end of the 1930s.

The segregation of Mexican children in Wyoming was never about solving an educational problem. It was about race. ${ }^{162}$ For Wyoming's White community, the Mexican School solidified racial boundaries, or as historian David Torres-Rouff aptly argued, "Segregated schools. . . simultaneously functioned as architects of race and as signifiers of Mexican Americans' subordinate status in the realm of social and political citizenship." 163 Some Wyomingites considered it similar to the racism Blacks experienced in the Jim Crow South. For instance, Susie Alamos, an alumna of the Mexican School in Worland, remembers:

\footnotetext{
${ }^{156}$ Dagley, "Wyoming Narrative Report," NARA, 15.

157 “Arithmetic Most Popular Subject at New Mexican Night School Here,” Worland Grit, Feb. 9, $1939,1$.

158“Re: Findings in the Sugar Beet Industry," Nov. 13, 1935, folder 20-164-8, box 98, RG 102, NARA.

${ }^{159}$ Mary Skinner to Mrs. McConnell, Nov. 3, 1935, folder: 20-164-5, box 98, RG 102, NARA; and Bryan Winston, "Mexican Community Formation in Nebraska: 1910-1950," Nebraska History 100, no. 1 (Spring 2019), 10.

${ }^{160}$ Sara Brown and Robie Sargent, Children Working in the Sugar Beet Fields of the North Platte Valley of Nebraska (New York: National Child Labor Committee, 1924), 67.

161 "Re: Findings in the Sugar Beet Industry," Nov. 13, 1935, folder 20-164-8, box 98, RG 102, NARA.

${ }^{162}$ García, Yosso, and Barajas, "A Few of the Brightest, Cleanest, Mexican Children," 8.

${ }^{163}$ Torres-Rouff, "Becoming Mexican," 93.
} 


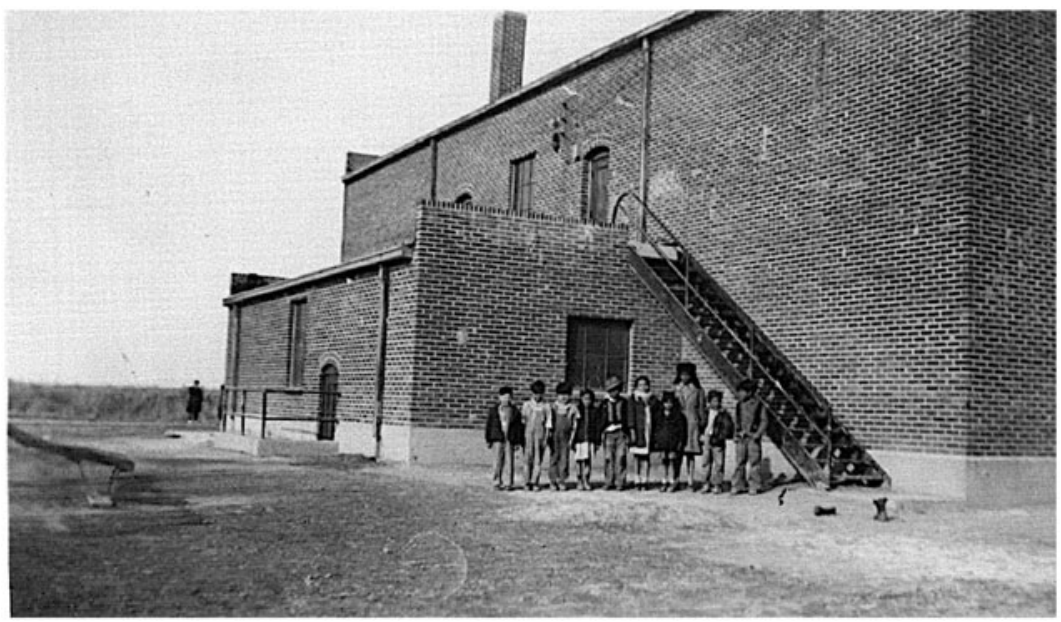

Figure 4. Mexican children standing in back of segregated school in Worland. Source: T. Joe Sandoval, "A Study of Some Aspects of the Spanish-Speaking Population in Selected Communities in Wyoming" (master's thesis, University of Wyoming, 1946), 85.

We came from a town where they treated you like colored people.... In fact, I'll tell you how bad that town was, while we stayed there so long, they built us our own school, they wouldn't let us go with los gabochos [Whites] to school. They did our own school and we had to go to the Mexican school. ${ }^{164}$

White community members like John Davis also remember the segregated experience:

I didn't go to school with a single person of Mexican descent until the sixth grade; they had a separate (but probably not equal) school called the "Spanish school." We on the east side of the tracks didn't think much about this situation, just seeing it as the way life was lived. Hispanic kids sure did; they were very sensitive to being discriminated against. ${ }^{165}$

These recollections were distinctly different from the public face of the government. In 1941, the WPA travel guide for Wyoming depicted the state as "a land of opportunity. . . where few questions are asked of a newcomer concerning his past or ancestry. It is not altogether rhetoric that man is accepted for what he is and

\footnotetext{
${ }^{164}$ Susie Alamos interview, in Elizabeth Mendoza, "The Mexicanization of the Yakima Valley, 19402007" (bachelor's thesis, Dartmouth College, 2008), 43 (in author's possession); and Sandoval, "A Study of Some Aspects," 65.

${ }^{165}$ John Davis, "The Good and the Bad from Then and Now," Northern Wyoming Daily News, Jan. 28, 2014, 4. For an account of desegregation in Worland, see Minutes, Sept. 11, 1956, Board of Trustees, Board Meeting of Worland School District, WSCR; Smotherman interview, LCP. According to Smotherman's account, integration in Worland was piecemeal until completed in the 1960s. This description substantiates the description in Jennifer Majera, The Borderlands of Race: Mexican Segregation in a South Texas Town (Austin: University of Texas Press, 2015), 2.
} 
what he can do." ${ }^{\prime 166}$ Such publications portrayed racial segregation in the state's schools as an abnormality of the territorial era, with the rest of narrative barely mentioning Mexican Americans. Such a glowing depiction of the "Equality State" contradicted the lived experience and unpublished WPA material of Mexicans in Wyoming. While one WPA report found that there were fewer "prejudices against Mexicans in certain circles that one would find directed against the negro group," it also found that "in other communities the prejudice against the Mexicans would be greater than that manifested against the negroes." 167 Mexicans and Blacks were interchangeable in the racial hierarchy of Wyoming and they were both targets of racial segregation. ${ }^{168}$ In fact, oral histories indicate that the few Black students who lived in Worland were forced to attend the Mexican School as well. ${ }^{169}$ This association is important given that Black children were the only group ever named in the permissive segregation law of Wyoming. ${ }^{170}$

At the same time, WPA racial element reports vilified Mexicans for their unwillingness to assimilate and become Americanized. ${ }^{171}$ They depicted German Russians as a group that blended in and were "hard to distinguish from other men and women of the community." 172 It was not that Mexicans were unwilling to assimilate; they were not allowed to enter the American mainstream. At one time, Mexicans and German Russian were treated as the same group in educational matters, but by the end of the 1930s, German Russians were distinguished from Mexicans, signaling the Mexicans' racial standing as non-White. The Japanese were described as a conditional "model minority" - they did not pose a racial problem because they were a small population, they did not marry outside their race, and their children were excellent students. ${ }^{173}$ However, this was not the case for the Mexican populace, who was defined as distinct from all other racial groups and the only group targeted for

\footnotetext{
${ }^{166}$ Federal Writers' Project, Wyoming: A Guide to Its History, Highways, and People (New York: Oxford University Press, 1941), 5-6.

${ }^{167}$ Dagley, "Wyoming Narrative Report," NARA, 63-65.

${ }^{168}$ Augustine Redwine, "Lovell's Mexican Colony," Annals of Wyoming 51, no. 2 (Fall 1979), 33-34. In Powell, Black and Mexican children were grouped together in special census counts. See Park County Superintendent of School Reports, "Annual Report of the Superintendent of Schools to the Board of School Trustees for the Fiscal Year Ending June 20, 1936," Annual Report of Country Superintendent 1936-1937, Wyoming Reports, WSA.

${ }^{169}$ Smotherman interview, LCP.

${ }^{170}$ T. A. Larson, History of Wyoming, 2nd ed. (Lincoln: University of Nebraska Press, 1990), 226; and A. C. Monahan and Katherine M. Cook, Educational Survey of Wyoming (Washington, DC: Government Printing Office, 1917), 12.

${ }^{171}$ For one report that particularly vilified Mexicans, see Helen T. Hence, "Racial Elements [Platte County]," WPA \#1363, WPAC.

${ }^{172}$ Smith, "Racial Elements [Washakie County]"; and "Worland, Wyoming," WPAC.

${ }^{173}$ Although less pronounced in Wyoming, David G. García found a similar view of the Japanese community before World War II in his study of Oxnard, California. See García, Strategies of Segregation, 76; Smith, "Racial Elements [Washakie County]," WPAC. For more on "conditional inclusion" and the periodization of the "model minority myth" that is usually associated as a post-World War II development, see Madeline Y. Hsu and Ellen D. Wu, "Smoke and Mirrors': Conditional Inclusion, Model Minorities, and the Pre-1965 Dismantling of Asian Exclusion," Journal of American Ethnic History 34, no. 4 (Summer 2015), $46-47$.
} 
segregation in the WPA reports. ${ }^{174}$ The WPA reports indicated that the "Mexican or Spanish race" recently had a segregated settlement built for them and also that "plans were being made at present to build a school for the Mexican children, locating it in their own locality." ${ }^{175}$ The descriptions portrayed the group, in educational terms, as not making much progress in school, and that "not many graduate from High School." 176 That so much attention was paid to Mexican differences and their schooling illuminates how schooling was viewed as a race problem not just in this Wyoming community but in the state.

\section{Conclusion}

W. E. B. Du Bois discussed the notion of the "Immortal Child" in his first autobiography, Darkwater. He argued that "in the treatment of the child the world foreshadows its own future and faith." 177 This observation was not lost on Mexican parents in Wyoming. A 1935 Children's Bureau report that included northern Wyoming noted that Mexicans found the segregation of their children the worst aspect of anti-Mexican sentiment, viewing it as a manifestation of pure race and social discrimination. ${ }^{178}$ Both Du Bois and Mexican parents recognized the distinct place child welfare and, by extension, public schooling played in manifesting racism and the future of race itself.

This analysis of Wyoming demonstrates the role of schools in structuring Whiteness in the absence of laws and legislation. In Wyoming, no laws named Mexicans or Spanish speakers as a specific group of people in any sense. By all measures-naturalization laws, miscegenation laws, education codes-Mexicans were part of the White race. The only institutions that specifically named Mexican or Spanish speakers as a race were public schools and classrooms. Not only did schools and classrooms structure Mexicans as a distinct race but they also associated the Spanish language with immigration and non-Whiteness-despite the fact that many German Russian immigrants did not speak English either, and the fact that most Mexican American children were fluent English speakers. As historian Rosina Lozano has demonstrated, this effectively racialized and nationalized Spanish as a non-US language, bound to Latin America (especially Mexico) and native only to non-Whites. $^{179}$

The experience of Mexican children in Wyoming schools during the Great Depression should complicate the assumption that schools and educational policies were tangential to racial history in the United States. Educational professionals exerted a powerful role in racialization in Wyoming, acting as a substitute for formal Jim Crow laws by being the final decision-makers in the segregation of Mexican

\footnotetext{
${ }^{174}$ Historian Natalia Molina defines these descriptions as "racial scripts." See Molina, How Race Is Made in America, 7.

175"New Mexican Colony Nearing Completion" (Worland) Wyoming News, Oct. 12, 1935, 3; Smith, "Racial Elements [Washakie County]," WPAC; "Worland, Wyoming," WPAC.

${ }^{176}$ Smith, "Racial Elements," 4.

${ }^{177}$ William Edward Burghardt Du Bois, Darkwater: Voices from within the Veil (New York: Harcourt, Brace and Howe, 1920), 202.

${ }^{178}$ Johnson, Welfare of Families, 80-81.

${ }^{179}$ Lozano, An American Language, 16, 177-78.
} 
children. In some cases, White school officials superseded White parent demands for segregating Mexican children, thus actively creating and maintaining racial integration. In many others, White educators and parents-both European immigrant and US-born-worked together with federal and state assistance to enact segregation. ${ }^{180}$ Ultimately, I found the necessity of expanding the scope of Mexican American educational histories beyond the Southwest and from a racial relational lens. ${ }^{181}$ Wyoming illuminates that almost everywhere Mexican settlement occurred, some form of racial segregation in public schooling followed. ${ }^{182}$ Most importantly, the segregation of Mexican children effectively nullified any claims to Whiteness Mexicans had, making public schools the architects of the "Mexican race."

Gonzalo Guzmán (gguzman1@colgate.edu) is a visiting assistant professor in foundations of education at Colgate University. His research focuses on the racialization and educational histories of ethnic Mexican communities in the Mountain States and Pacific Northwest of the US. He thanks Rubén Donato, David G. García, and Joy Williamson-Lott for their comments on earlier drafts of this article, as well as the $H E Q$ editors and anonymous reviewers for their helpful feedback.

\footnotetext{
${ }^{180}$ For one such example, C. H. Studebaker to Grace Raymond Hebard, Dec. 11, 1929, box 3, folder 1, GRHP.

${ }^{181}$ Rosina Lozano, "New Directions in Latino/a/x Histories of Education: Comparative Studies in Race, Language, Law and Higher Education," History of Education Quarterly 60, no. 4 (Nov. 2020), 613-14.

${ }^{182}$ For example, a segregated Mexican school was also established in Billings, Montana. See Nina Faye Anderson, "History of Elementary Education in Billings, Montana" (master's thesis, University of California at Los Angeles, 1947), 144-45; Ruth N. Meyer, "The History of Billings City Schools 1879 to 1936" (unpublished manuscript, Billings Public Library, May 14, 1936), 23; and Laurie Mercier, "Creating a New Community in the North: Mexican Americans of the Yellowstone Valley," in Stories from an Open Country: Essays on the Yellowstone River Valley, ed. William L. Lang (Billings: Western Heritage Press, 1995), 130.
}

Cite this article: Gonzalo Guzmán, “Things change you know': Schools as the Architects of the Mexican Race in Depression-Era Wyoming," History of Education Quarterly 61, no. 4 (November 2021), 392-422. https://doi.org/10.1017/heq.2021.37. 